\title{
Human health risk associated to particulate matter and polycyclic aromatic hydrocarbon levels and their relation with preponderant sources in Gran La Plata, Argentina
}

\author{
Daniela Giuliani $^{1}\left[\right.$ ] Jorge Esteban Colman Lerner ${ }^{2} \cdot$ Andrés Porta $^{1}$ \\ Received: 28 October 2020 / Accepted: 21 February 2021 / Published online: 5 March 2021 \\ (C) The Author(s), under exclusive licence to Springer-Verlag GmbH Germany, part of Springer Nature 2021
}

\begin{abstract}
Levels of suspended particulate matter (PM) of both fractions $\mathrm{PM}_{10}$ and $\mathrm{PM}_{2.5}$ in ambient air were monitored in three areas of Gran La Plata: industrial, urban, and residential (2017-2019). Associated polycyclic aromatic hydrocarbons (PAHs) and nitropolycyclic aromatic hydrocarbons (NPAHs) to PM were also determined and possible emission sources were identified. Assessment of health risk to PM exposure and associated compounds was realized. Results showed a decrease in levels of $\mathrm{PM}_{10}$ in each area along the period studied, especially in the industrial area. Decreases in $\mathrm{PM}_{2.5}$ levels were also observed in urban and residential areas over the years, although the trend is not as marked as with $\mathrm{PM}_{10}$ levels. Then, $\mathrm{PM}_{2.5}$ levels in the industrial area have remained practically constant. The $89 \%$ of both $\mathrm{PM}_{10}$ and $\mathrm{PM}_{2.5}$ annual mean exceeds the WHO reference values. The presence of most of the 16 US EPA priority PAHs studied was found with a detection frequency greater than $60 \%$ and it was possible to identify the importance of the contributions of vehicular emissions as predominant sources of PAH emission. From the calculations of the risk of contracting cancer throughout life (LCR), in the case of adults, the US EPA limits were not complied in the industrial and urban areas and in both fractions of PM. From the evaluation of the burden of disease (EBD), the calculated relative risks of mortality were very similar for the studied districts, being the relative risk in La Plata slightly lower, about 3-5\%, than those in Berisso and Ensenada.
\end{abstract}

Keywords PM $\cdot$ PAHs $\cdot$ Vehicular emissions $\cdot$ Lifetime cancer risk $\cdot$ Environmental burden of disease $\cdot$ Gran La Plata Argentina

\section{Introduction}

Air pollution represents a huge risk for human health. Three of the ten main sources of global mortality are attributable to air pollution, like tobacco smoke, burning solid fuels in households, and exposure to atmospheric particulate matter (PM) (Donahue 2018).

Responsible Editor: Lotfi Aleya

Daniela Giuliani

dgiuliani@quimica.unlp.edu.ar

1 CIM, Centro de Investigaciones del Medio Ambiente, CONICET CCT La Plata, Universidad Nacional de La Plata, Bv. 120 n $^{\circ}$ 1489 La Plata, Argentina

2 CINDECA, Centro de Investigación y Desarrollo en Ciencias Aplicadas "Dr. Jorge J. Ronco" CONICET CCT La Plata, UNLP, 47 $\mathrm{N}^{\circ} 257,1900$ La Plata, Argentina
According to the World Health Organization (WHO), 91\% of the worldwide population lives in places where the air quality levels exceed the WHO guideline limits. About 4.2 million of premature deaths in the world are related to air pollution, mainly due to heart disease, stroke, chronic obstructive pulmonary disease (COPD), lung cancer, and acute respiratory infections in children (WHO 2019).

In 2013, the International Agency for Research on Cancer (IARC) concluded that exposure to polluted ambient air causes lung cancer (Group 1, carcinogenic to humans). Similarly, PM, which is one of the main pollutants of air pollution, was included in Group 1 and it is considered carcinogenic to humans (Loomis et al. 2013; WHO - IARC 2016).

PM can originate from natural or anthropogenic sources. Particles are emitted directly to the atmosphere or are formed by means of transformation of gaseous emissions. By knowing the aerodynamic diameter and chemical composition of particles, it is possible to obtain information about their possible sources. PM is commonly classified by its size; therefore, $\mathrm{PM}_{10}$ is the coarse fraction of $\mathrm{PM}$, where particles have 
aerodynamic diameter minor to $10 \mu \mathrm{m}$; and $\mathrm{PM}_{2.5}$ is the fine fraction of PM, where particles have aerodynamic diameter minor to $2.5 \mu \mathrm{m}$. The chemical composition of tropospheric particles includes inorganic ions, metallic compounds, elemental carbon, organic compounds, and crustal substances. This heterogeneity of particles and the fact that their potential of causing health effects varies with their size make it difficult to attribute direct health effects to PM exposure (US.EPA 2009; Vallero 2014; WHO 2005, 2016).

Polycyclic aromatic hydrocarbons (PAHs) are composed of two or more fused aromatic rings. They are ubiquitous environmental pollutants but mostly they are spread in the atmosphere and they are formed by pyrolysis or incomplete combustion of organic matter. Pyrolysis of organic matter at high temperature produces fragments of molecules and radicals, which when combined together form PAHs. Composition of pyrosynthesis products depends on the type of fuel and the period of high temperatures. The main source of emission of PAHs is the combustion of fossil fuels (Cheruiyot et al. 2015; Hayakawa 2018).

PAHs are present in the atmosphere in very small quantities (ng $\mathrm{m}^{-3}$ of air) and in two possible forms: adsorbed to suspended particles and gaseous. About $70-90 \%$ of these compounds are adsorbed in particles with smaller diameter than $5 \mu \mathrm{m}$ (mainly fine particles, smaller than $2.5 \mu \mathrm{m}$ ), which can enter the human respiratory system penetrating deep into the lungs causing different health effects. There are several studies which show that many of the PAHs are carcinogenic and/or mutagenic (Fang et al. 2020; Massolo 2004; Nemmar et al. 2013).

Nitropolycyclic aromatic hydrocarbons (NPAHs) are derivatives of PAHs with at least one nitro group attached to their aromatic rings. These compounds are directly emitted into the atmosphere or they also can be formed in it (Atkinson and Arey 1994; Bandowe and Meusel 2017; Liu et al. 2006; Nagato 2018). NPAHs are semivolatile and like PAHs they can exist in two forms in the atmosphere, gaseous or adsorbed to PM. Usually, they are present in smaller quantities than PAHs, with concentrations that differ by more than an order of magnitude (Kielhorn et al. 2003; Nagato 2018); however, they can be significantly toxic to human health, such as kidney and liver damage, and an increased risk of skin, lung, bladder, and gastrointestinal cancers (del Rosario Sienra and Rosazza 2006; Hayakawa 2018; Mastandrea et al. 2005).

There is abundant epidemiologic evidence which associates chronic exposure to pollutants related to petrochemical industry and vehicular traffic, with health effects on the development and function of the lungs and cardiovascular system and increased mortality (Amoatey et al. 2020; Pope et al. 2011; Wichmann et al. 2009); Wong et al. 2008).

Negative effects of airborne PM are well documented, such as the association of fine particulate pollution with all-cause, lung cancer, and cardiopulmonary mortality (Lippmann 2014; Pope et al. 2011; Rückerl et al. 2011). There is no evidence of a
PM level that does not produce adverse effects on human health according to the WHO, since, even with low concentrations of $\mathrm{PM}$, the risk to the health of the population is significant (WHO 2013). There is an important burden of disease attributed to PM pollution, which reduces life expectancy in almost 9 months in Europe, and more than $80 \%$ of the population living in urban areas in the world are exposed to levels that exceed the Air Quality Guidelines from the WHO (Goldstone 2015). When levels of PM are very high (greater than $150 \mu \mathrm{g} \mathrm{m}^{-3}$, US EPA standard value for $24 \mathrm{~h} \mathrm{PM}_{10}$ ), such as those found in cities from India and China, air pollutants can trigger irritating effects and inflammatory effects on neuroreceptors from respiratory tracts and from the epithelium. Those high exposure levels of PM rare time are found in countries of Europe and in North America (Frampton et al. 2013; Lu et al. 2015; Wu et al. 2018).

Many epidemiologic and toxicological studies show that $\mathrm{PM}_{2.5}$ is a strong risk indicator associated with exposure to PM from diverse sources and in different environments, pointing out that exposure to $\mathrm{PM}_{2.5}$ is associated to systemic inflammation, oxidative stress, alteration of electric processes in the heart, and vascular dysfunction (Gomes and Florida-James 2014; Lippmann 2014; Lu et al. 2015; Nelin et al. 2012; Rückerl et al. 2011). Other studies show that exposure levels of $\mathrm{PM}_{2.5}$ determine the causes of mortality. On the one hand, if the levels of PM are low, cardiovascular mortality prevails other diseases, but on the other hand, if the levels of PM are high, lung cancer mortality prevails (Lippmann 2014; Pope et al. 2011).

Regarding long-term exposure to fine PM, other illnesses have been described besides cardiovascular and respiratory diseases. Evidence suggests effects on diabetes, neurological development in children, and neurological disorders in adults (Eze et al. 2015; Genc et al. 2012; Pope et al. 2011).

There are two main potential sources of air pollution in the study area, Gran La Plata. One of the sources is a group of petrochemical industries (including the main oil refinery of the country and a calcined petroleum coke plant), together with other production companies such as thermal power plants and metallurgical manufacturing, located in the districts of Ensenada and Berisso. The other important source of air pollution is vehicular traffic, mainly in the city center of La Plata.

The aim of this study is to analyze the levels of suspended $\mathrm{PM}_{10}$ and $\mathrm{PM}_{2.5}$ in ambient air of Gran La Plata during the period of March 2017-June 2019, analyze PAHs and NPAHs associated to PM, identify possible emission sources, and evaluate associated health risk to such compounds.

\section{Materials and methods}

\section{Study area and monitoring sites}

City of La Plata is the capital city of Buenos Aires province, Argentina. Gran La Plata is an urban agglomeration and is 
formed by the districts of La Plata, Ensenada, and Berisso, with an estimated total population of 932.493 inhabitants (INDEC 2010). The study area is located in the Humid Pampa region, characterized by its plainness and its uniform morphology (Lauría and VVAA 2011).

Figure 1 shows the three monitoring sites that were selected from previous studies on levels of particulate matter (PM) and volatile organic compounds (VOCs) in the region and according to the characteristics of the area, such as population, economy activities, and main sources of air pollution (Colman Lerner et al. 2014; Giuliani 2020; Rehwagen et al. 2005). The sites are the following: industrial (I, $34^{\circ} 54^{\prime} 19.0^{\prime \prime} \mathrm{S}$ and $57^{\circ} 55^{\prime} 34.7^{\prime \prime} \mathrm{W}$ ), urban (U, $34^{\circ} 55^{\prime} 04.7^{\prime \prime} \mathrm{S}$ and $57^{\circ} 56^{\prime} 39.1^{\prime \prime}$ $\mathrm{W}$ ), and residential ( $\mathrm{R}, 34^{\circ} 53^{\prime} 11.44^{\prime \prime} \mathrm{S}$ and $\left.58^{\circ} 1^{\prime} 53.95^{\prime \prime} \mathrm{W}\right)$. The I site is located in both districts, Ensenada and Berisso, and it is about $5 \mathrm{~km}$ away from the city center of La Plata. It is characterized for having the most important petrochemical complex in Argentina. The $\mathrm{U}$ site is in the city center of $\mathrm{La}$ Plata, and it is characterized for a high vehicular traffic of cars, motorcycles, and heavy vehicles from the public transport. The R site is located relatively far away from the industrial area and it has less vehicular traffic than the city center of $\mathrm{La}$ Plata. It has residential houses and is located between rural areas. Previous studies, from 5 to 10 years ago, considered this residential area as a control area; however, in recent years, new studies show significant growth in terms of population, new buildings, and number of vehicles (Colman Lerner et al. 2014; Massolo et al. 2010).

\section{Sampling of PM, extraction, and analytical determination of PAHs and NPAHs}

Three PM sampling devices were used: two low-volume sampler MiniVol TAS and one low-volume sampler TDA, connected to a pump (Gilian, AirCon-2) (Fig. 2). Each device was located in one of the three monitoring sites, I, U, and R. PM samples were collected on fiberglass and quartz filters (Whatman) of $46.2 \mathrm{~mm}$ in diameter. The monitoring was carried out seasonally between the years 2017 and 2019, showing the number of samples for each zone and year in Table 3 . The monitoring of each fraction of particulate matter $\left(\mathrm{PM}_{10}\right.$ or $\mathrm{PM}_{2.5}$ ) was carried out simultaneously between the different sites (R, U, and I).

Filters were kept in a container with silica gel until sampling, in order to keep the filters without any trace of humidity. Sampling volumes were selected according to the methodology from other authors (Colman Lerner 2013; Sosa et al. 2017) and in order to obtain determinable quantities of PM mass in the balance $( \pm 0.1 \mathrm{mg}$, Ohaus Pioneer PA214). Volumes were $21.6 \mathrm{~m}^{3}$ for $\mathrm{PM}_{10}$ samples and $36 \mathrm{~m}^{3}$ for $\mathrm{PM}_{2.5}$ samples. Operation flow rates were $5 \mathrm{~L} \mathrm{~min}^{-1}$ for the MiniVol TAS sampler and $16.6 \mathrm{~L} \mathrm{~min}^{-1}$ for the TDA sampler.

At the end of each sampling, filters were placed in the container with silica gel for $48 \mathrm{~h}$ to eliminate any trace of humidity. PM mass was determined by gravimetric method; therefore, each one of the filters was weighted before and after sampling. Then, PM concentration in the air $\left(\mu \mathrm{g} \mathrm{m}^{-3}\right)$ was

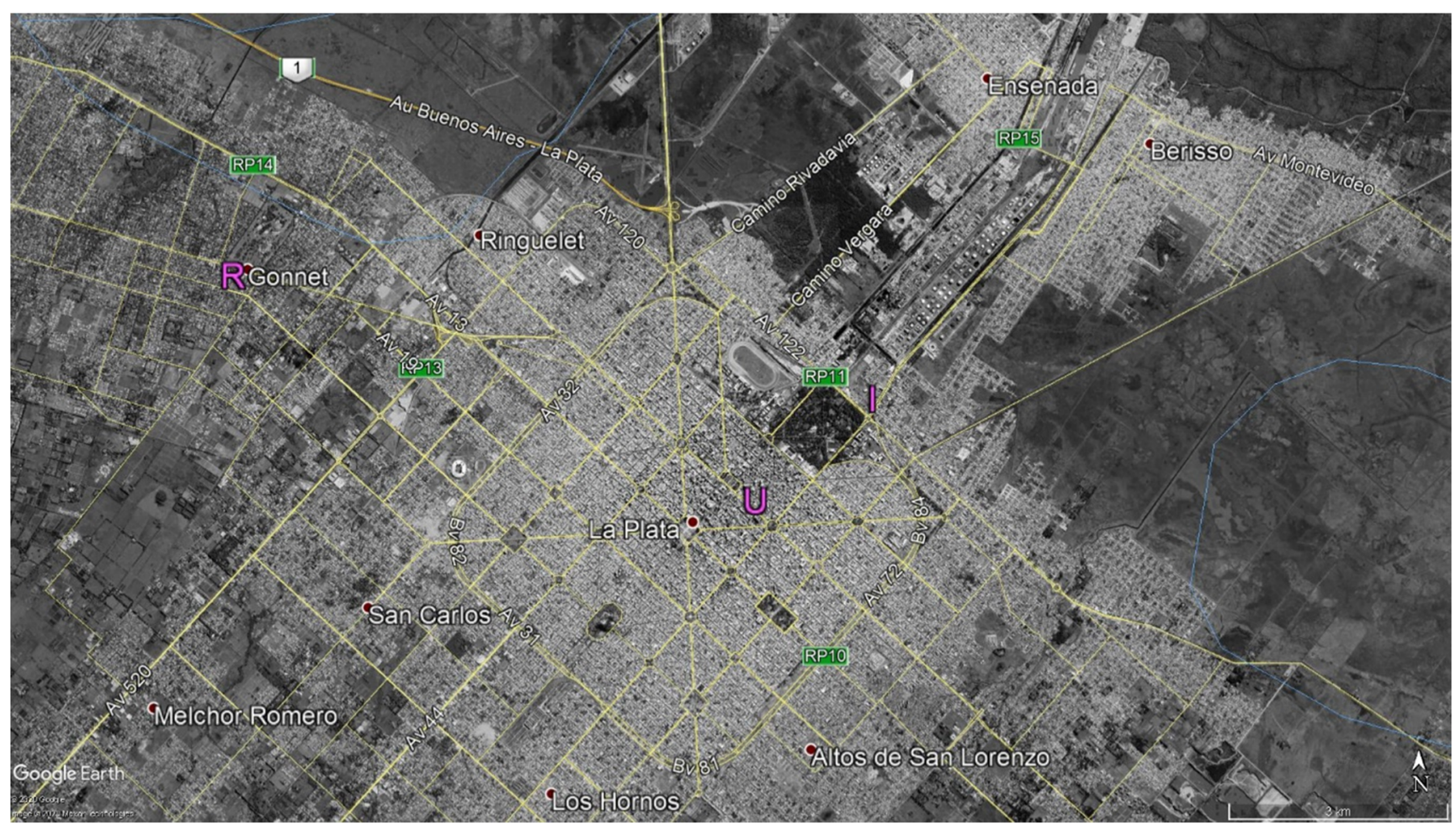

Fig. 1 Monitoring sites: industrial (I), urban (U), and residential (R) 
Fig. 2 On the left is the TDA sampler. On the right is the MiniVol TAS sampler

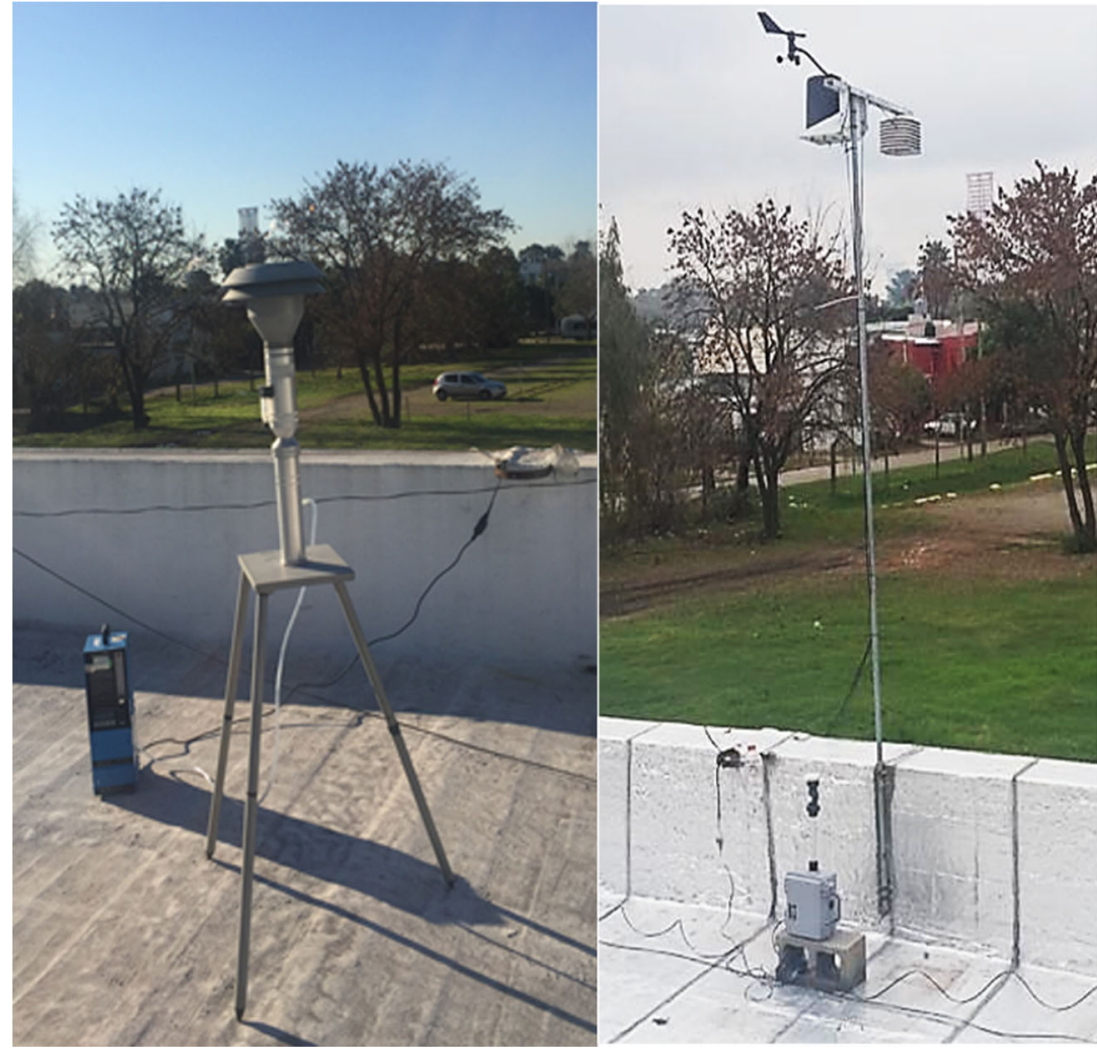

calculated obtaining the ratio between PM mass and sampling volume.
Regarding pollutants adsorbed to PM, 16 US EPA priority PAHs and other 4 NPAHs were selected (Table 1). Extraction
Table 1 Studied PAHs and NPAHs. Recovery factors $(R)$, standard deviation $(\sigma)$, method detection limit (MDL), retention time $\left(t_{\mathrm{R}}\right)$, and ions searched $(\mathrm{m} / \mathrm{z})$

\begin{tabular}{llllll}
\hline PAH & $R$ & $\sigma$ & MDL $\left(\mathrm{ng} \mathrm{m}^{-3}\right)$ & $t_{\mathrm{R}}(\mathrm{min})$ & $\mathrm{m} / \mathrm{z}$ \\
\hline Naphthalene (Nap) & 0.807 & 0.033 & 1.61 & 6.24 & $127,128,129$ \\
Acenaphthylene (Acy) & 0.829 & 0.013 & 1.08 & 9.25 & $151,152,153$ \\
Acenaphthene (Ace) & 0.919 & 0.234 & 1.61 & 9.51 & $151,152,153$ \\
Fluorene (Flu) & 0.989 & 0.037 & 1.69 & 10.34 & $165,166,167$ \\
Phenanthrene (Phe) & 0.760 & 0.058 & 1.17 & 11.89 & $176,178,179$ \\
Anthracene (Ant) & 0.594 & 0.006 & 1.56 & 12.03 & $177,178,179$ \\
Fluoranthene (Fl) & 0.750 & 0.021 & 2.11 & 14.24 & $101,202,203$ \\
Pyrene (Py) & 0.874 & 0.141 & 1.50 & 14.83 & $200,202,203$ \\
Benzo(a)anthracene (BaA) & 0.915 & 0.034 & 2.09 & 18.91 & $226,228,229$ \\
Chrysene (Chry) & 1.043 & 0.196 & 2.00 & 19.06 & $226,228,229$ \\
Benzo(b)fluoranthene (BbF) & 0.827 & 0.160 & 0.50 & 22.90 & $125,126,250$ \\
Benzo(k)fluoranthene (BkF) & 0.927 & 0.109 & 1.67 & 22.81 & $125,126,250$ \\
Benzo(a)pyrene (BaP) & 1.030 & 0.209 & 1.53 & 23.99 & $125,126,252$ \\
Dibenzo(a,h)anthracene (DBahA) & 0.963 & 0.030 & 0.53 & 28.54 & $138,274,276$ \\
Benzo(g,h,i)perylene (BghiP) & 0.845 & 0.058 & 1.97 & 28.69 & $138,274,276$ \\
Indeno(1,2,3-c,d)pyrene (IP) & 0.901 & 0.021 & 1.89 & 27.85 & $138,274,276$ \\
9-Nitroanthracene (9-N-Ant) & 0.619 & 0.01 & 5.14 & 11.51 & $177,178,223$ \\
1-Nitropyrene (1-N-Py) & 1.01 & 0.06 & 5.47 & 13.95 & $200,202,247$ \\
6-Nitrochrysene (6-N-Chry) & 1.03 & 0.03 & 4.58 & 18.52 & $226,228,273$ \\
6-Nitrobenzo(a)pyrene (6-N-BaP) & 0.456 & 0.02 & 5.17 & 13.85 & $126,252,297$ \\
\hline & & & & &
\end{tabular}


from each filter was performed with 2 additions of $5 \mathrm{~mL}$ of dichloromethane (U.V.E., HPLC grade) and an ultrasonic bath (TESTLAB TB10, Power: $400 \mathrm{~W}$, Frequency: $40 \mathrm{kHz}$ ) for $30 \mathrm{~min}$ after each addition of dichloromethane. Then, it was dried with nitrogen flow from a nitrogen generator (Agilent) and $1 \mathrm{~mL}$ of acetonitrile was added (PHARMCOAAPER, HPLC quality). Finally, extracts were sieved through 0.22- $\mu$ m-poresize filters (Colman Lerner 2013; Sosa et al. 2017).

Extracts were analyzed by gas chromatography coupled to mass spectrometry (Thermo Scientific 1300-ISQ, SIM mode (single ion method)). Chromatographic conditions were as follows: column TR-5MS $(30 \mathrm{~m} \times 0.25 \mathrm{~mm} \times 0.25 \mu \mathrm{m})$, constant flow of $2.00 \mathrm{~mL} \mathrm{~min}^{-1}$, split injector $250{ }^{\circ} \mathrm{C}, 50.0 \mathrm{~mL} \mathrm{~min}{ }^{-1}$ (split ratio 25 ), and injection volume of $1 \mu \mathrm{L}$. Temperature ramp: $40{ }^{\circ} \mathrm{C}(1 \mathrm{~min}), 15^{\circ} \mathrm{C} / \mathrm{min} \mathrm{h} / 210{ }^{\circ} \mathrm{C}(1 \mathrm{~min}), 5^{\circ} \mathrm{C} / \mathrm{min}$ $\mathrm{h} / 310^{\circ} \mathrm{C}(1 \mathrm{~min})$. Recovery factors $(R)$ were determined for each analyte following methodology from Colman Lerner (2013) and Sosa et al. (2017), and they are shown in Table 1, together with method detection limit (MDL), retention time $\left(t_{\mathrm{R}}\right)$, and target ions $(\mathrm{m} / \mathrm{z})$ for each analyte.

\section{Statistical analysis}

Results were analyzed employing descriptive statistic and the nonparametric Mann-Whitney test, which determines statistically significant differences between two independent samples. XLSTAT software (Addinsoft 2019) was employed for statistical analysis and the differences were considered significant when $p<0.05$ (Giuliani et al. 2017).

\section{Risk associated with PM and PAH levels}

\section{Lifetime cancer risk calculation}

There is an equation for the estimation of the specific contribution to the risk of developing cancer from pollutant exposure. This equation uses information provided by organizations such as the WHO, US EPA, and IARC. The calculation requires knowing carcinogenic potency of the specific compound and the mean exposure of the target group. Therefore, lifetime cancer risk (LCR) associated to benzo(a)pyrene (IARC Group 1, carcinogenic to humans) was calculated using Eq. (1) by multiplication of the chronic daily intake (CDI) by the IRIS system potency factor (PF) (IRIS: Integrated Risk Information System) of the compound and by the absorption factor (AF). The absorption factor of the PAHs for human was supposed to be $90 \%$ (Colman Lerner et al. 2014; Massolo et al. 2010; Sosa et al. 2017). In this study, LCR was calculated for outdoor exposure in children and adults.

$\mathrm{LCR}=\mathrm{CDI} \times \mathrm{PF} \times \mathrm{AF}$
CDI, in milligram per kilogram per day, was calculated with Eq. (2):

$$
\begin{aligned}
\mathrm{CDI}= & (\mathrm{CC} \times \mathrm{IR} \times \mathrm{ED} \times \mathrm{EF} \times \mathrm{LE}) \\
& \div(\mathrm{BW} \times \mathrm{AT} \times \mathrm{NY})
\end{aligned}
$$

where $\mathrm{CC}$ is the contaminant concentration (median in $\mathrm{mg}$ $\left.\mathrm{m}^{-3}\right)$, IR is the inhalation rate $\left(0.417 \mathrm{~m}^{3} \mathrm{~h}^{-1}\right.$ for children and $0.833 \mathrm{~m}^{3} \mathrm{~h}^{-1}$ for adults), and ED is the exposure duration and the value is $56 \mathrm{~h}^{-1} \mathrm{wee}^{-1}$ since the average time that people are exposed to outside air is $8 \mathrm{~h}$ per day, which gives the value of $56 \mathrm{~h}$ per week. EF is the exposure frequency (52 weeks year $^{-1}$ ) and LE is the length of exposure and the values are 9 years for children and 40 years for adults, which represent the average age used for the children and adult population, respectively. BW is the body weight (30 kg for children and $70 \mathrm{~kg}$ for adults), ATL is the average lifetime (period over which exposure is averaged, 70 years), and NY is the number of days per year (365 days). These reference values were taken from the methodology of Colman Lerner et al. (2014).

LCR for the other priority PAHs analyzed in this study was calculated using the equivalent toxic in relation to the benzo(a)pyrene (B(a)Peq), which is the most toxic of the PAHs (Nisbet and LaGoy 1992). Therefore, B(a)Peq is obtained by multiplication of the $\mathrm{PAH}$ concentration (median) by the corresponding toxic equivalent factor (TEF). Finally, the addition of all B(a)Peq is the total toxic equivalent concentration (Colman Lerner et al. 2018; Sosa et al. 2017; Vargas et al. 2013).

\section{Environmental burden of disease calculation}

Environmental burden of disease for ambient air pollution was estimated according to the WHO guidelines (Ostro et al. 2004). In this method, population exposure is based on concentrations of $\mathrm{PM}_{10}$ and $\mathrm{PM}_{2.5}$ since there are many epidemiologic studies that show a relationship between mortality and morbidity, and daily and long-term exposure, with pollutant concentrations, including PM (Dominici et al. 2002; Schwartz 2000). Mortality impacts are mostly probable to occur among risk groups of people, such as elderly people with preexistent cardiovascular and respiratory diseases, and among children.

There are 4 main components in this assessment method and they are the following:

- Assessment of the ambient exposure of the population to $\mathrm{PM}_{10}$ and $\mathrm{PM}_{2.5}$ levels, based on fixed monitors or estimations from mathematical models. Also, it is a necessary background or target concentration as a comparison.

- Determination of the size of exposed population to $\mathrm{PM}_{10}$ and $\mathrm{PM}_{2.5}$, and the type of health effect of interest. 
- Mortality rate in the population by the type of health effect studied.

- Concentration-response functions from epidemiologic studies which relate ambient $\mathrm{PM}_{10}$ and $\mathrm{PM}_{2.5}$ concentration to the selected health effects.

In this study, three health outcomes were determined:

1. Number of cases of premature mortality from all causes from short-term exposure to $\mathrm{PM}_{10}$, for people of all ages.

2 . Number of cases of premature mortality from cardiopulmonary diseases attributed to long-term exposure to $\mathrm{PM}_{2.5}$, for people older than 30 years.

3. Number of cases of premature mortality from lung cancer attributed to long-term exposure to $\mathrm{PM}_{2.5}$, for people older than 30 years.

Table 2 shows relative risk (RR) functions used for each health outcome:

Once RR was calculated, attributable fraction (AF) of health effects from air pollution was obtained (Eq. 3):

$\mathrm{AF}=(\mathrm{RR}-1) \div \mathrm{RR}$

where AF is the proportion of the environmental burden of disease attributable to PM.

Finally, number of expected deaths due to air pollution was obtained as follows (Eq. 4):

$E=\mathrm{AF} \times B \times P$

where $E$ is the expected number of deaths due to outdoor air pollution; $B$ is the incidence of the given health effect on the population, expressed as annual rate mortality; and $P$ is the relevant exposed population for the health effect.

\section{Results and discussion}

\section{$\mathrm{PM}_{10}$ and $\mathrm{PM}_{2.5}$ levels}

Table 3 and Figs. 3 and 4 show annual concentrations of $\mathrm{PM}_{10}$ and $\mathrm{PM}_{2.5}$ from study each area, along with minimum and maximum values.

Table 2 Relative risk functions. $X$ is the pollutant concentration in $\mu \mathrm{g}$ $\mathrm{m}^{-3} \cdot X_{0}$ is the target concentration in $\mu \mathrm{g} \mathrm{m}^{-3}$

\begin{tabular}{llll}
\hline & Relative risk function & Suggested $\beta$ coefficient & Subgroup \\
\hline $\mathrm{RR}_{1}$ & $\mathrm{RR}=\exp \left(\beta\left(X-X_{0}\right)\right)$ & 0.0008 & All ages \\
$\mathrm{RR}_{2}$ & $\mathrm{RR}=\left((X+1) /\left(X_{0}+1\right)\right)^{\beta}$ & 0.15515 & $>30$ years \\
$\mathrm{RR}_{3}$ & $\mathrm{RR}=\left((X+1) /\left(X_{0}+1\right)\right)^{\beta}$ & 0.23218 & $>30$ years \\
\hline
\end{tabular}

Observing $\mathrm{PM}_{10}$ levels along the study period in each area, there was a trend in their levels in I, showing a decrease from 2017 to 2019 , with a statistically significant decrease from 2018 to 2019. Tables 4 and 5 show all the results of the Mann-Whitney test. Then, $\mathrm{PM}_{10}$ levels in U were practically constant during the study period. Lastly, R levels in 2018 were the highest $\left(24.3 \mathrm{\mu g} \mathrm{m}^{-3}\right)$ and then, there was a decrease towards 2019, where level of PM was the lowest level $\left(14.7 \mathrm{\mu g} \mathrm{m}^{-3}\right.$ ) from the period.

When comparing between areas, $\mathrm{PM}_{10}$ levels in 2017 followed a trend where I levels were higher than those in $U$, and $U$ levels were greater than those in $\mathrm{R}$. Then, there was the same trend in 2018 and 2019, where U levels were the highest, and I levels were slight higher than those in R.

Regarding $\mathrm{PM}_{2.5}$, I levels were practically constant during the period 2017-2019, while U levels were constant in 2017 and 2018, and then, there was a slight decrease from 2018 to 2019. Lastly, $\mathrm{R}$ levels were the highest in $2017\left(17.5 \mathrm{\mu g} \mathrm{m}^{-3}\right)$, and there was an important decrease $\left(10.0 \mu \mathrm{g} \mathrm{m}^{-3}\right)$ at the end of the period.

When comparing between areas, in 2017, R levels were higher regarding the other areas. In 2018, I and U levels were very similar and higher than those in R. Lastly, in 2019, $\mathrm{PM}_{2.5}$ levels were higher than those in $\mathrm{R}$, and $\mathrm{R}$ levels were higher than those in $\mathrm{U}$.

The $\mathrm{PM}_{10}$ values (less than $10 \mu \mathrm{m}$ ) in general include coarse particles (greater than $2.5 \mu \mathrm{m}$ ) mainly associated, in the region of study, with industrial sources and fine particles (less than $2.5 \mu \mathrm{m}$ ) associated in this case mainly with vehicular emissions; that is, $\mathrm{PM}_{10}$ values include the type of particles monitored in $\mathrm{PM}_{2.5}$. Table 6 shows the $\mathrm{PM}_{10} / \mathrm{PM}_{2.5}$ ratios, where it is evident that in site I the ratio remains constant, decreasing towards 2019, the opposite being in U and R. This can be explained by a greater influence of vehicle emissions (mainly associated with fine particles) compared to emissions of industrial origin, which in turn present a considerable decrease in zone I for the year 2019, which also influences the other monitoring sites.

It is possible to compare PM levels from this study with those disposed by local legislation of Buenos Aires province, which are $50 \mu \mathrm{g} \mathrm{m}^{-3}$ for $\mathrm{PM}_{10}$ and $25 \mu \mathrm{g} \mathrm{m}^{-3}$ for $\mathrm{PM}_{2.5}$, both as annual allowed maximum (OPDS 2018). However, levels proposed by the WHO are more exigent, being $20 \mathrm{\mu g} \mathrm{m}^{-3}$ for $\mathrm{PM}_{10}$ and $10 \mu \mathrm{g} \mathrm{m}^{-3}$ for $\mathrm{PM}_{2.5}$ (WHO 2005). On the one hand, all annual means of $\mathrm{PM}_{10}$ and $\mathrm{PM}_{2.5}$ are below values from local legislation, with the only exception of annual mean of $\mathrm{PM}_{2.5}$ in the $\mathrm{R}$ site in $2017\left(25.3 \mu \mathrm{g} \mathrm{m}^{-3}\right)$, which slightly exceeds $25 \mathrm{\mu g} \mathrm{m}^{-3}$. On the other hand, when comparing with WHO values, $89 \%$ of both, $\mathrm{PM}_{10}$ and $\mathrm{PM}_{2.5}$ annual means, exceed reference values. This fact points out the large difference between local legislation and the WHO guidelines and the need of an urgent review and update in local legislation. 
Table $3 \quad \mathrm{PM}_{10}$ and $\mathrm{PM}_{2.5}$ concentrations in $\mu \mathrm{g} \mathrm{m}^{-3} . N$ number of samples

\begin{tabular}{|c|c|c|c|c|c|c|c|c|c|c|c|c|}
\hline \multirow[b]{2}{*}{$\mathrm{PM}_{10}$} & \multicolumn{4}{|l|}{ I } & \multicolumn{4}{|l|}{$\mathrm{U}$} & \multicolumn{4}{|l|}{$\mathrm{R}$} \\
\hline & Mean & Median & Min-max & $N$ & Mean & Median & Min-max & $N$ & Mean & Median & Min-max & $N$ \\
\hline 2017 & 39.2 & 35.1 & $9.2-68.8$ & 6 & 28.9 & 28.4 & $4.6-59.5$ & 6 & 27.5 & 18.1 & $8.9-65.0$ & 4 \\
\hline 2018 & 27.8 & 27.8 & $13.9-46.3$ & 11 & 29.5 & 32.4 & $13.5-41.2$ & 9 & 28.5 & 24.3 & $22.1-41.9$ & 6 \\
\hline 2019 & 16.0 & 18.1 & $4.6-23.2$ & 4 & 25.4 & 27.2 & $16.5-32.4$ & 3 & 21.4 & 14.7 & $13.2-36.3$ & 3 \\
\hline $\mathrm{PM}_{2.5}$ & Mean & Median & Min-max & $N$ & Mean & Median & Min-max & $N$ & Mean & Median & Min-max & $N$ \\
\hline 2017 & 23.1 & 14.1 & $13.8-47.2$ & 5 & 14.8 & 11.2 & $8.4-28.5$ & 4 & 25.3 & 17.5 & $11.0-55.4$ & 4 \\
\hline 2018 & 16.0 & 12.4 & $8.3-36.0$ & 7 & 14.5 & 12.8 & $5.7-36.1$ & 8 & 11.3 & 8.4 & $5.4-18.5$ & 5 \\
\hline 2019 & 11.6 & 12.5 & $5.6-16.7$ & 3 & 7.2 & 7.2 & $6.2-8.3$ & 2 & 10.7 & 10.0 & $6.0-16.2$ & 3 \\
\hline
\end{tabular}

\section{PAHs associated to PM}

Tables 7 and 8 show PAH and NPAH concentrations associated to $\mathrm{PM}_{10}$ and $\mathrm{PM}_{2.5}$ for each area and for the entire studied period. Additionally, they show the detection frequency for each compound. Furthermore, Fig. 5 shows evolution of total PAH levels along the period, for each area and PM fraction.

First of all, results show that 15 of the 16 priority PAHs were found in $\mathrm{PM}_{10}$ and 11 of these 15 PAHs were detected with a frequency of $60 \%$ or more. Only naphthalene was not detected in $\mathrm{PM}_{10}$. Regarding $\mathrm{PM}_{2.5}, 14 \mathrm{PAHs}$ were detected and 10 of these 14 PAHs were detected with a frequency of $60 \%$ or more. Only naphthalene and pyrene were not detected in $\mathrm{PM}_{2.5}$. The most toxic PAH, benzo(a)pyrene, which is categorized by the IARC as Group 1 (Lyall et al. 1988), was found in both PM fractions and in the three study areas, with high frequency $\left(84 \%\right.$ in $\mathrm{PM}_{10}$ and $97 \%$ in $\mathrm{PM}_{2.5}$ ). Additionally, dibenzo(a,h)pyrene, which is categorized as $2 \mathrm{~A}$ by the IARC (probably carcinogenic to humans), was found in both PM fractions and in the three study areas, with high frequency (72\% in $\mathrm{PM}_{10}$ and $88 \%$ in $\mathrm{PM}_{2.5}$ ). Regarding the 4 NPAHs studied, they were not detected in any PM

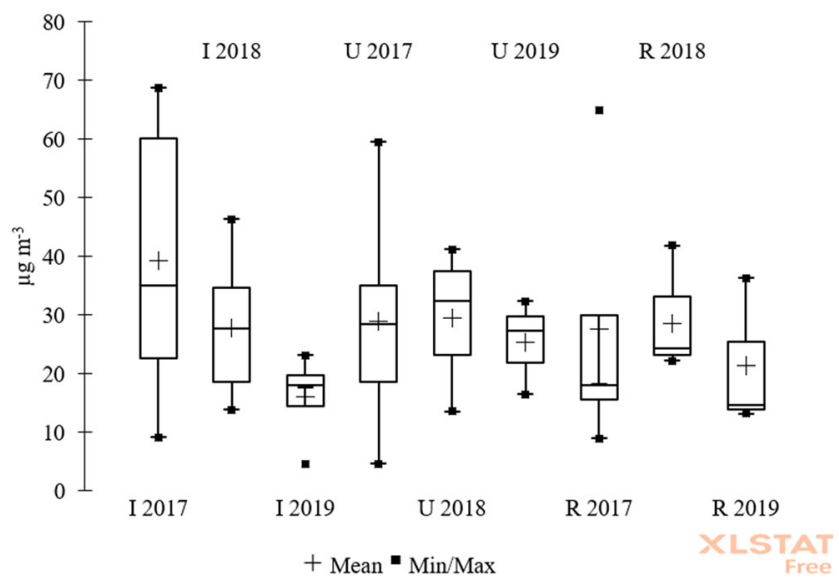

Fig. 3 Box plots of annual $\mathrm{PM}_{10}$. The bottom and top of the boxes are the 25 th and 75 th percentiles respectively, and the band near the middle of the boxes shows the 50 th percentile (the median) fraction, probably due to that the precursor PAHs were not detected or were detected in very low concentrations.

There is a trend observed every year and in both PM fractions for several PAHs, where levels are higher in I than those in $\mathrm{U}$, and then, $\mathrm{U}$ levels are slightly higher than those in R (I $>\mathrm{U}>\mathrm{R}$ ). Moreover, this fact is reflected in the levels of total PAHs (see Fig. 5) and evidenced the contribution of those compounds from industrial processes with incomplete combustion reactions, such as coal calcination. Another important source of PAHs is vehicular traffic, since combustion of different fuels produces and emits those compounds (Ravindra et al. 2008). The slight difference between total PAH levels in $\mathrm{U}$ and $\mathrm{R}$ is a possible indication that both areas have the same relevant source of emission, such as vehicular traffic.

Additionally, important information is obtained from the analysis of PAH composition according to their molecular weight (MW). PAHs are classified according to the number of aromatic rings in the molecule as follows: PAHs with 2 or 3 rings are low molecular weight PAHs (LMW-PAHs), PAHs with 4 rings are medium molecular weight PAHs (MMWPAHs), and PAHs with 5 or 6 rings are high molecular weight PAHs (HMW-PAHs). Figure 6 shows a graphical

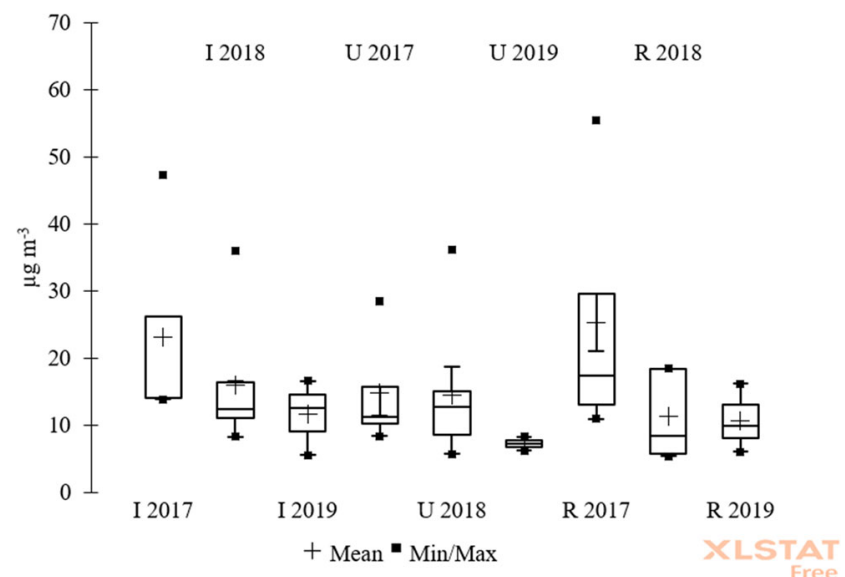

Fig. 4 Box plots of annual $\mathrm{PM}_{2.5}$. The bottom and top of the boxes are the 25 th and 75 th percentiles respectively, and the band near the middle of the boxes shows the 50th percentile (the median) 
Table 4 Mann-Whitney test results, comparison of areas per year for $\mathrm{PM}_{10}$ and $\mathrm{PM}_{2.5}$

\begin{tabular}{lll}
\hline 2017 & 2018 & 2019 \\
\hline $\mathrm{PM}_{10}$ & & \\
Industrial-urban, $p$ value $=0.589$ & Industrial-urban, $p$ value $=0.872$ & Industrial-urban, $p$ value $=0.4$ \\
Industrial-residential, $p$ value $=0.352$ & Industrial-residential, $p$ value $=0.833$ & Industrial-residential, $p$ value $=0.857$ \\
Urban-residential, $p$ value $=0.914$ & Urban-residential, $p$ value $=0.864$ & Urban-residential, $p$ value $=0.7$ \\
$\mathrm{PM}_{2.5}$ & & Industrial-urban, $p$ value $=0.8$ \\
Industrial-urban, $p$ value $=0.190$ & Industrial-urban, $p$ value $=0.779$ & Industrial-residential, $p$ value $=1$ \\
Industrial-residential, $p$ value $=0.905$ & Industrial-residential, $p$ value $=0.530$ & Urban-residential, $p$ value $=0.8$ \\
Urban-residential, $p$ value $=0.393$ & Urban-residential, $p$ value $=0.435$ &
\end{tabular}

representation of the profile of PAHs according to their molecular weights. Results show that, in both PM fractions and the three areas, about $15-25 \%$ of total PAHs are MMW-PAHs and they are associated to diesel emissions and coal combustion (Fang et al. 2020; Quiterio et al. 2007). Then, there are very similar proportions of HMW-PAHs in U and R areas in both fractions of PM. This suggests that HMW-PAHs have the same relevant source and they are commonly associated to vehicle exhaust (Fang et al. 2020; Oliveira et al. 2014). Besides, there are very similar proportions of LMW-PAHs in $\mathrm{U}$ and $\mathrm{R}$, while in I, this proportion is always at least $10 \%$ higher. This suggests a contribution of LMW-PAHs from industrial processes that emit these compounds, such as power plants using fossil fuel and petroleum refining (Oliveira et al. 2014; Ravindra et al. 2008).

Furthermore, as shown in Fig. 7, when comparing total PAHs in $\mathrm{PM}_{10}$ with total PAHs in $\mathrm{PM}_{2.5}$, $\mathrm{PAH}$ concentration in $\mathrm{PM}_{10}$ is higher in the three areas, although this difference is larger for I and much smaller for $\mathrm{U}$ and $\mathrm{R}$. This large difference between PM fractions in I might indicate an important contribution from industrial emissions such as combustion processes where the coarse fraction is impregnated with this type of organic compounds, besides from the contribution of vehicular traffic emissions. In the other areas, $U$ and $R$, it is possible to associate origin of PAHs in $\mathrm{PM}_{2.5}$, mostly to incomplete combustion from vehicular emissions. The slight difference between $\mathrm{PM}_{10}$ and $\mathrm{PM}_{2.5}$ in these areas could be attributed to the contribution to $\mathrm{PM}_{10}$ from airborne pollutants transported from the petrochemical complex.

\section{PAH diagnostic ratios}

Since many years ago, vehicular emissions have been identified as one of the main PAH sources to the environment (Khalili et al. 1995; Marr et al. 1999). Formation mechanisms of PAHs in mobile sources are through pyrosynthesis and emissions depend on some factors such as type of engine, composition of fuel, mileage, PAH content in lubricant oils, lubricant oil combustion, ways of driving, and control devices of emissions like air filters (Katsoyiannis 2014; Ravindra et al. 2008).

Differences in PAH composition of emissions from diverse sources depend on raw material and fuels used. These differences in PAH proportions can be used for tracking and source identification purposes, by means of the calculation of different concentration ratios of PAHs (Fang et al. 2020).

The ratio values used as reference are not equivalent to exact indicators, since these ratios are only indicative and depend on many factors, whether it is the type of fuel used, the technology of the vehicles (age of the vehicle fleet), the use of catalytic systems, or the air/fuel ratio, etc. Although there is not only one value for each ratio of PAHs, since there are several values published by more than one author, the calculation of these ratios allows having an idea of which are the relevant sources of PAHs (Fu et al. 2010; Quiterio
Table 5 Mann-Whitney test results, pairs of years compared by area for $\mathrm{PM}_{10}$ and $\mathrm{PM}_{2.5}$

\begin{tabular}{lll}
\hline Industrial & Urban & Residential \\
\hline $\mathrm{PM}_{10}$ & & \\
$2017-2018, p$ value $=0.445$ & $2017-2018, p$ value $=0.689$ & $2017-2018, p$ value $=0.257$ \\
$2017-2019, p$ value $=0.114$ & $2017-2019, p$ value $=0.905$ & $2017-2019, p$ value $=0.857$ \\
$2018-2019, p$ value $=0.041$ & $2018-2019, p$ value $=0.5$ & $2018-2019, p$ value $=0.257$ \\
$\mathrm{PM}_{2.5}$ & & \\
$2017-2018, p$ value $=0.268$ & $2017-2018, p$ value $=0.933$ & $2017-2018, p$ value $=0.190$ \\
$2017-2019, p$ value $=0.25$ & $2017-2019, p$ value $=0.133$ & $2017-2019, p$ value $=0.229$ \\
$2018-2019, p$ value $=0.833$ & $2018-2019, p$ value $=0.267$ & $2018-2019, p$ value $=1$ \\
\hline
\end{tabular}


Table $6 \mathrm{PM}_{10} / \mathrm{PM}_{2.5}$ ratios in each area and year of study

\begin{tabular}{llll}
\hline & \multicolumn{3}{l}{$\mathrm{PM}_{10} / \mathrm{PM}_{2.5}$} \\
\cline { 2 - 4 } & $\mathrm{I}$ & $\mathrm{U}$ & $\mathrm{R}$ \\
\hline 2017 & 2.49 & 2.54 & 1.03 \\
2018 & 2.24 & 2.53 & 2.89 \\
2019 & 1.45 & 3.78 & 1.47 \\
\hline
\end{tabular}

et al. 2007). However, ratios must be used with precaution since frequently there are significant overlaps between them and they can be altered due to reactivity and volatility of some PAHs (Manoli et al. 2004).

In practice, care must be taken with the environmental samples when using these reference ratios, because the concentrations of PAHs obtained come from multiple sources (gasoline vehicles, diesel vehicles, and industrial emissions, among others). The ratio values obtained may overlap by more than one range (e.g., gasoline and diesel emissions). What is relevant about the use of these ratios is the importance of evaluating whether the values are closer to a particular type of emission, in this case the evaluation of the contribution of vehicle emissions (diesel or gasoline) with respect to other types of emissions (industrial, such as oil refineries).

Table 9 shows the $\mathrm{PAH}$ ratios calculated for $\mathrm{PM}_{10}$ and $\mathrm{PM}_{2.5}$ and the three areas of study:

The ratio $\mathrm{BaA} /(\mathrm{BaA}+\mathrm{Chry})$ is used to evaluate vehicular emissions, with a value of 0.33 for gasoline vehicles (Gogou et al. 1996) and a value between 0.38 and 0.65 for diesel vehicles (Kavouras et al. 2001; Sienra et al. 2005). The ratios obtained in this study in $\mathrm{U}$ and $\mathrm{R}$ for both $\mathrm{PM}_{10}$ and $\mathrm{PM}_{2.5}$ are related to diesel emissions. In the case of I, the ratio is superior to the diesel emission range for $\mathrm{PM}_{10}$, probably due to the influence of industrial emissions. However, the ratio for $\mathrm{PM}_{2.5}$ corresponds to diesel emissions, and the reason might be that PM with vehicular origin has a larger proportion of fine particles, minor to $2.5 \mu \mathrm{m}$ (Cheng et al. 2013; Wong et al. 2019).

The ratio IP/(IP+BghiP) can be associated with diesel emissions, when values are between 0.30 and 0.70 (Kavouras et al. 2001; Sienra et al. 2005). In this study, all values obtained are in that range, confirming the importance of PAH emissions of vehicular origin.

Finally, the ratio $\sum \mathrm{C}-\mathrm{PAHs} / \sum \mathrm{PAHs}$ is the sum of the concentrations of 9 of the PAHs (Fl, Py, BaA, BbF, BkF, BaP,

Table 7 PAH concentrations in $\mathrm{PM}_{10}\left(\mathrm{ng} \mathrm{m}^{-3}\right) . N$ number of samples

\begin{tabular}{|c|c|c|c|c|c|c|c|c|c|c|}
\hline & \multicolumn{10}{|l|}{$\mathrm{PM}_{10}$} \\
\hline & \multicolumn{3}{|l|}{ I } & \multicolumn{3}{|l|}{$\mathrm{U}$} & \multicolumn{3}{|l|}{$\mathrm{R}$} & \multirow{2}{*}{$\begin{array}{l}\text { Detection } \\
\text { frequency }(\%)\end{array}$} \\
\hline & Mean & Median & Min-max & Mean & Median & Min-max & Mean & Median & Min-max & \\
\hline Ace & 3.18 & 3.31 & $2.05-3.89$ & 2.15 & 2.02 & $1.79-2.80$ & 1.75 & 1.71 & $1.62-1.97$ & 35 \\
\hline Acy & 3.25 & 3.60 & $1.53-4.05$ & 1.65 & 1.66 & $1.17-2.03$ & 1.37 & 1.36 & $1.19-1.58$ & 35 \\
\hline Ant & 30.72 & 28.02 & $15.75-59.78$ & 12.47 & 11.23 & $6.55-22.35$ & 8.52 & 8.23 & $4.89-12.34$ & 100 \\
\hline $\mathrm{BaA}$ & 8.52 & 7.10 & $2.58-19.24$ & 4.95 & 4.34 & $2.23-9.55$ & 3.46 & 3.06 & $2.20-6.21$ & 91 \\
\hline $\mathrm{BaP}$ & 5.47 & 4.21 & $2.09-13.47$ & 3.64 & 3.28 & $1.70-7.09$ & 2.70 & 2.94 & $1.61-4.19$ & 84 \\
\hline $\mathrm{BbF}$ & 3.49 & 2.51 & $0.55-8.71$ & 2.29 & 1.79 & $0.73-5.41$ & 1.98 & 1.92 & $0.64-3.76$ & 84 \\
\hline BghiP & 7.32 & 4.84 & $2.28-19.65$ & 4.48 & 3.25 & $2.07-10.35$ & 3.93 & 3.33 & $2.07-7.24$ & 95 \\
\hline $\mathrm{BkF}$ & 4.04 & 3.02 & $1.70-8.49$ & 3.03 & 2.41 & $1.72-5.67$ & 2.26 & 1.90 & $1.75-3.02$ & 60 \\
\hline Chry & 2.76 & 2.32 & $2.11-4.24$ & 2.63 & 2.51 & $2.05-3.67$ & 2.35 & 2.33 & $2.03-2.71$ & 44 \\
\hline DBahA & 3.70 & 3.41 & $1.96-6.25$ & 2.06 & 1.52 & $0.74-4.63$ & 1.50 & 1.03 & $0.64-3.27$ & 72 \\
\hline $\mathrm{Fl}$ & 4.47 & 4.65 & $2.17-6.28$ & 2.92 & 3.09 & $2.17-3.67$ & 2.53 & 2.61 & $2.14-2.86$ & 63 \\
\hline Flu & 9.68 & 9.86 & $2.68-19.45$ & 4.76 & 4.20 & $1.82-8.69$ & 3.13 & 2.43 & $1.72-5.97$ & 100 \\
\hline IP & 7.63 & 6.66 & $3.14-15.25$ & 4.12 & 3.37 & $1.93-8.59$ & 3.03 & 2.64 & $2.06-4.76$ & 98 \\
\hline Nap & $<\mathrm{LD}$ & $<\mathrm{LD}$ & $<\mathrm{LD}$ & $<\mathrm{LD}$ & $<\mathrm{LD}$ & $<\mathrm{LD}$ & $<\mathrm{LD}$ & $<\mathrm{LD}$ & $<\mathrm{LD}$ & 0 \\
\hline Phe & 6.71 & 5.98 & $2.23-15.97$ & 4.24 & 2.88 & $1.55-9.46$ & 2.97 & 2.50 & $1.23-6.27$ & 100 \\
\hline Py & 1.99 & 1.99 & $1.89-2.09$ & 1.94 & 1.94 & $1.79-2.09$ & $<\mathrm{LD}$ & $<\mathrm{LD}$ & $<\mathrm{LD}$ & 9 \\
\hline 9-N-Ant & $<\mathrm{LD}$ & $<\mathrm{LD}$ & $<\mathrm{LD}$ & $<\mathrm{LD}$ & $<\mathrm{LD}$ & $<\mathrm{LD}$ & $<\mathrm{LD}$ & $<\mathrm{LD}$ & $<\mathrm{LD}$ & 0 \\
\hline 1-N-Py & $<\mathrm{LD}$ & $<\mathrm{LD}$ & $<\mathrm{LD}$ & $<\mathrm{LD}$ & $<\mathrm{LD}$ & $<\mathrm{LD}$ & $<\mathrm{LD}$ & $<\mathrm{LD}$ & $<\mathrm{LD}$ & 0 \\
\hline 6-N-Chry & $<\mathrm{LD}$ & $<\mathrm{LD}$ & $<\mathrm{LD}$ & $<\mathrm{LD}$ & $<\mathrm{LD}$ & $<\mathrm{LD}$ & $<\mathrm{LD}$ & $<\mathrm{LD}$ & $<\mathrm{LD}$ & 0 \\
\hline 6-N-BaP & $<\mathrm{LD}$ & $<\mathrm{LD}$ & $<\mathrm{LD}$ & $<\mathrm{LD}$ & $<\mathrm{LD}$ & $<\mathrm{LD}$ & $<\mathrm{LD}$ & $<\mathrm{LD}$ & $<\mathrm{LD}$ & 0 \\
\hline$\sum$ PAHs & 89.86 & 75.59 & $34.39-174.71$ & 46.43 & 30.11 & $22.92-99.66$ & 33.76 & 28.38 & $13.99-65.24$ & \\
\hline $\mathrm{N}$ & 18 & & & 15 & & & 10 & & & \\
\hline
\end{tabular}


Table 8 PAH concentrations in $\mathrm{PM}_{2.5}\left(\mathrm{ng} \mathrm{m}^{-3}\right) . N$ number of samples

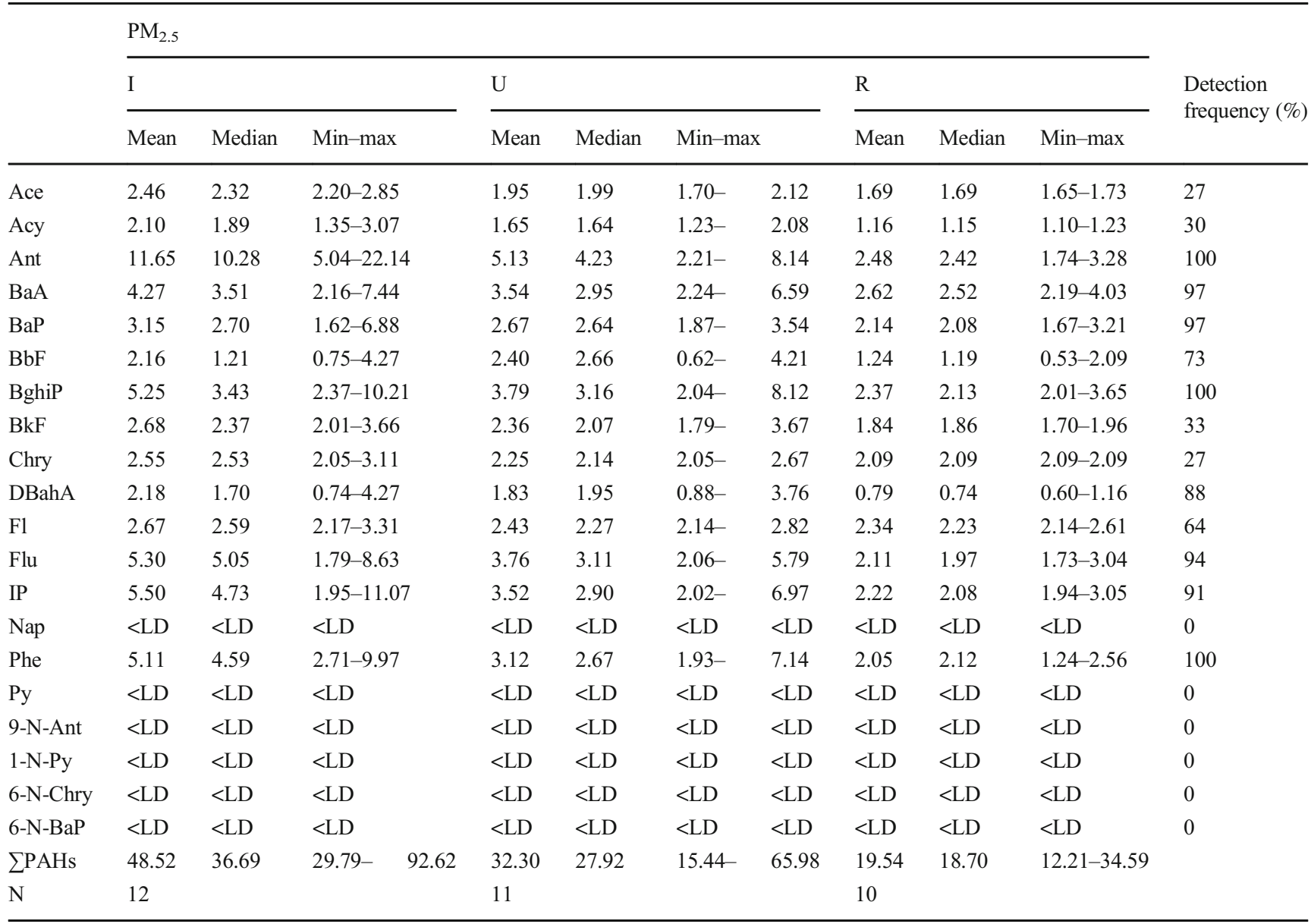

BeP, IP y BghiP) divided by the sum of all PAHs. A value of 0.30 is associated with diesel emissions, and values in the range of $0.41-0.60$ are associated with gasoline emissions (Quiterio et al. 2007). In this work, BeP (benzo(e)pyrene) was not included in the calculation because it was not determined. The ratios obtained in $\mathrm{U}$ and $\mathrm{R}$, for $\mathrm{PM}_{10}$ and $\mathrm{PM}_{2.5}$,

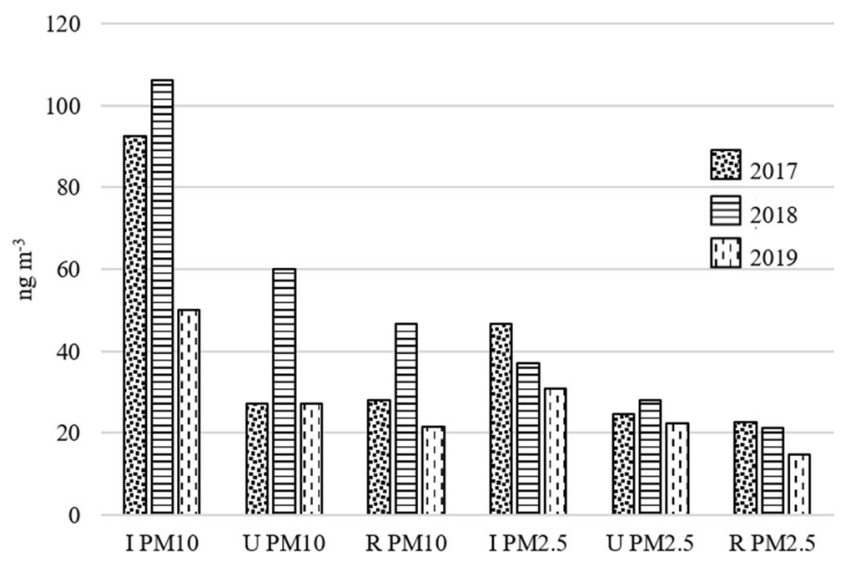

Fig. 5 Evolution of total PAH levels (medians) in $\mathrm{ng} \mathrm{m}^{-3}$ in each area and PM fraction and in I for $\mathrm{PM}_{2.5}$, correspond to gasoline emissions. However, the ratio in I for $\mathrm{PM}_{10}(0.39)$ is minor to gasoline emissions range but higher than diesel emissions value, which makes it difficult to discern if it is due to a greater contribution

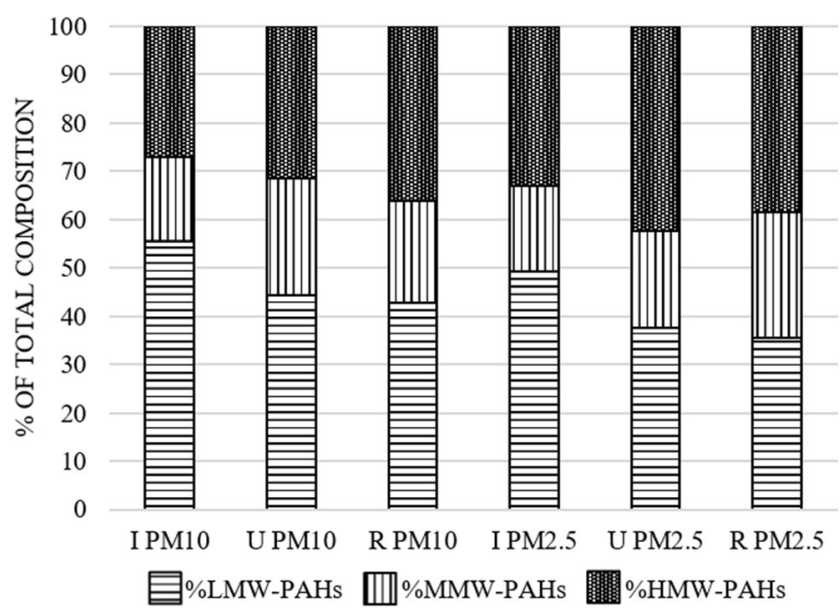

Fig. 6 Profile of PAH composition in each area and PM fraction according to their MW 


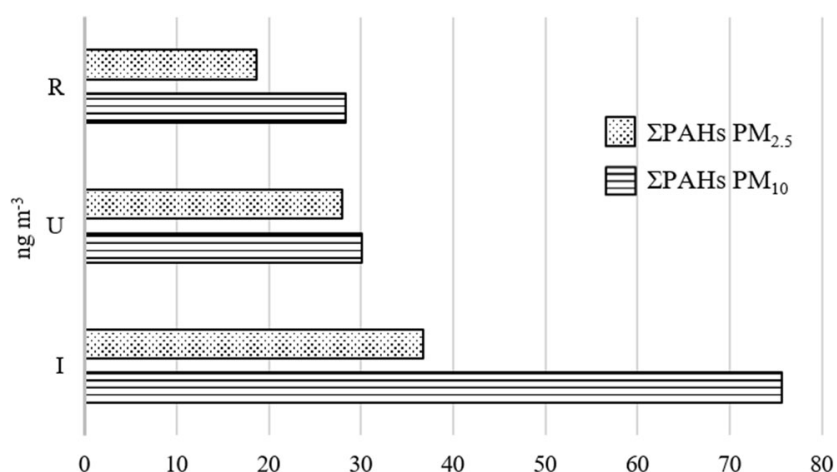

Fig. 7 Comparison of total PAH concentration $\left(\mathrm{ng} \mathrm{m}^{-3}\right)$ in the entire study period, between $\mathrm{PM}_{2.5}$ and $\mathrm{PM}_{10}$

of diesel emissions or due to the influence of emissions of industrial origin.

These results agree with those obtained by Oliveira et al. (2014), where it was found that contribution of PAHs and PM from vehicular emissions is important, even in the vicinity of a petrochemical complex.

\section{Lifetime cancer risk}

Table 10 shows TEF values for each PAH and the contribution from each one to the total sum of carcinogenic PAHs in $\mathrm{PM}_{10}$ and $\mathrm{PM}_{2.5}$. There are four compounds that contribute the highest proportion: $\mathrm{BaP}, \mathrm{DBahA}, \mathrm{BaA}$, and IP. They represent around $90-91 \%$ of the total $\mathrm{PAH}$ in each area and fraction of $\mathrm{PM}$.

$\mathrm{BaP}$ is the compound that contributes most in every area and in both PM fractions, with values that range from 46 to $57 \%$, and the highest values are in $\mathrm{R}\left(57 \%\right.$ in $\mathrm{PM}_{10}$ and $58 \%$ in $\mathrm{PM}_{2.5}$ ). The second compound that contributes the most is DBahA, with values ranging from 20 to $34 \%$.

Once B(a)Peq from each PAH was calculated, LCR was obtained (Table 11). The WHO considers that LCR value is acceptable if it is in the range of $1 \times 10^{-5}$ and $1 \times 10^{-6}$, whereas the US EPA considers that LCR value has to be minor to $1 \times 10^{-6}$ (Chen and Liao 2006; Colman Lerner et al. 2014; WHO 2000).

Table 9 PAH ratios in I, U, and $\mathrm{R}$ for $\mathrm{PM}_{10}$ and $\mathrm{PM}_{2.5}$

\begin{tabular}{llll}
\hline & $\mathrm{BaA} /(\mathrm{BaA}+\mathrm{Chry})$ & $\mathrm{IP} /(\mathrm{IP}+\mathrm{BghiP})$ & $\sum \mathrm{C}-\mathrm{PAHs} / \sum \mathrm{PAHs}$ \\
\hline $\mathrm{PM}_{10} \mathrm{I}$ & 0.77 & 0.54 & 0.39 \\
$\mathrm{PM}_{10} \mathrm{U}$ & 0.69 & 0.50 & 0.44 \\
$\mathrm{PM}_{10} \mathrm{R}$ & 0.64 & 0.46 & 0.45 \\
$\mathrm{PM}_{2.5} \mathrm{I}$ & 0.68 & 0.52 & 0.46 \\
$\mathrm{PM}_{2.5} \mathrm{U}$ & 0.64 & 0.48 & 0.52 \\
$\mathrm{PM}_{2.5} \mathrm{R}$ & 0.66 & 0.48 & 0.57 \\
\hline
\end{tabular}

On the one hand, results show that LCR for children in $\mathrm{PM}_{10}$ and $\mathrm{PM}_{2.5}$ is below limits established by the WHO and US EPA. On the other hand, LCR values for adults accomplish the limits established by the WHO, but they exceed US EPA limits in both areas, I and U, and in both PM fractions, since they are higher than $1 \times 10^{-6}$. This is an alarming sign for the control organisms, and it shows the need of monitoring the levels of pollutants. Additionally, it is necessary to know that these values could be even higher, since other carcinogenic compounds, such as volatile organic compounds, were not considered in the calculation because they were not determined in this work.

\section{Environmental burden of disease}

The expected number of deaths $(E)$ due to air pollution was calculated for the districts of Gran La Plata: Berisso, Ensenada, and La Plata. Relative risk (RR) for each area was calculated using the mean concentrations of $\mathrm{PM}_{10}$ and $\mathrm{PM}_{2.5}$ from $\mathrm{I}$ for the districts of Berisso and Ensenada, and the mean concentrations corresponding to $\mathrm{U}$ were used for the district of La Plata. The calculation for $\mathrm{R}$ was not done because of the lack of information, such as mortality rates from that area. Background concentrations $\left(X_{0}\right)$ were $10 \mu \mathrm{g} \mathrm{m}^{-3}$ for $\mathrm{PM}_{10}$ and $3 \mu \mathrm{g} \mathrm{m}^{-3}$ for $\mathrm{PM}_{2.5}$, which are those taken as reference by the WHO guideline. Population data and mortality rate from all causes are average values from the last few years and they were obtained from a public database of the Ministry of Health of the Province of Buenos Aires (Ministerio de Salud n.d.). Mortality rate from cardiopulmonary diseases in the population over 30 years of age was estimated with the number of deaths from heart diseases, and mortality rate from lung cancer in the population over 30 years of age was estimated with the number of deaths from chronic diseases of the respiratory tract. Table 12 shows a summary of the values from each component of $E$.

Relative risks calculated for Berisso and Ensenada are the same, since they were calculated with PM concentrations from I. The difference between them is in the calculation of number of deaths $(E)$.

As results show, relative risk associated to death for all causes $\left(R_{1}\right)$ is very similar for the three districts. However, La Plata district has an 11 times greater population than Ensenada, and 7 times greater than Berisso, which in proportion results in a greater number of deaths in La Plata (81) than in Berisso (14) and Ensenada (9).

Then, relative risk associated to deaths from cardiopulmonary diseases $\left(\mathrm{RR}_{2}\right)$ calculated for La Plata is $3 \%$ lower than the ones calculated for Berisso and Ensenada. However, number of expected deaths in La Plata (235) is remarkably higher than in Berisso (35) and Ensenada (24), due to the greater population of La Plata. The attributable fractions (AF) indicate that $20.6 \%, 20.6 \%$, and $18.3 \%$ of deaths could be avoided in Berisso, Ensenada, and La Plata respectively if $\mathrm{PM}_{2.5}$ 
Table 10 Toxic equivalent factor and carcinogenic contribution from each PAH

\begin{tabular}{|c|c|c|c|c|c|c|c|}
\hline \multirow[b]{2}{*}{ PAHs } & \multirow[b]{2}{*}{ TEF } & \multicolumn{3}{|c|}{$\begin{array}{l}\mathrm{PAH} \text { total carcinogenic } \\
\text { contribution }(\%) \text { in } \mathrm{PM}_{10}\end{array}$} & \multicolumn{3}{|c|}{$\begin{array}{l}\text { PAH total carcinogenic } \\
\text { contribution }(\%) \text { in } \mathrm{PM}_{2.5}\end{array}$} \\
\hline & & I & $\mathrm{U}$ & $\mathrm{R}$ & I & $\mathrm{U}$ & $\mathrm{R}$ \\
\hline Ace & 0.001 & 0.03 & 0.03 & 0.03 & 0.04 & 0.03 & 0.05 \\
\hline Acy & & 0.00 & 0.00 & 0.00 & 0.00 & 0.00 & 0.00 \\
\hline Ant & 0.01 & 2.82 & 1.82 & 1.62 & 1.78 & 0.74 & 0.66 \\
\hline $\mathrm{BaA}$ & 0.1 & 7.15 & 7.03 & 6.04 & 6.09 & 5.13 & 6.89 \\
\hline $\mathrm{BaP}$ & 1 & 42.42 & 53.12 & 57.99 & 46.89 & 45.89 & 56.84 \\
\hline $\mathrm{BbF}$ & 0.1 & 2.52 & 2.90 & 3.78 & 2.10 & 4.62 & 3.25 \\
\hline BghiP & 0.01 & 0.49 & 0.53 & 0.66 & 0.60 & 0.55 & 0.58 \\
\hline $\mathrm{BkF}$ & 0.1 & 3.04 & 3.90 & 3.75 & 4.12 & 3.60 & 5.08 \\
\hline Chry & 0.01 & 0.23 & 0.41 & 0.46 & 0.44 & 0.37 & 0.57 \\
\hline DBahA & 1 & 34.36 & 24.62 & 20.32 & 29.52 & 33.90 & 20.22 \\
\hline $\mathrm{Fl}$ & 0.001 & 0.05 & 0.05 & 0.05 & 0.04 & 0.04 & 0.06 \\
\hline Flu & 0.001 & 0.10 & 0.07 & 0.05 & 0.09 & 0.05 & 0.05 \\
\hline IP & 0.1 & 6.71 & 5.46 & 5.21 & 8.21 & 5.03 & 5.68 \\
\hline Nap & 0.001 & 0.00 & 0.00 & 0.00 & 0.00 & 0.00 & 0.00 \\
\hline Phe & 0.001 & 0.06 & 0.05 & 0.05 & 0.08 & 0.05 & 0.06 \\
\hline Py & 0.001 & 0.02 & 0.03 & 0.00 & 0.00 & 0.00 & 0.00 \\
\hline B(a)Peq & & 100 & 100 & 100 & 100 & 100 & 100 \\
\hline
\end{tabular}

concentration was reduced to $3 \mu \mathrm{g} \mathrm{m}^{-3}$. Chalvatzaki et al. (2019) found similar results, where cardiopulmonary mortality could be prevented by $23.4 \%$ and $15.8 \%$ in Lisbon and Athens, respectively, if $\mathrm{PM}_{2.5}$ levels were close to $3 \mu \mathrm{g} \mathrm{m}^{-3}$.

Lastly, relative risk associated to deaths from lung cancer $\left(\mathrm{RR}_{3}\right)$ in La Plata is $5 \%$ lower than those in Berisso and Ensenada. Then, the number of expected deaths in La Plata (35) is higher than those in Berisso (5) and Ensenada (5), once again due to greater population of La Plata. The attributable fractions indicate that $29.2 \%, 29.2 \%$, and $26 \%$ of deaths from lung cancer could be prevented in Berisso, Ensenada, and La Plata respectively if $\mathrm{PM}_{2.5}$ levels were closer to the background concentration $3 \mu \mathrm{g} \mathrm{m}^{-3}$. Chalvatzaki et al. (2019) also found similar results, where lung cancer mortality could be prevented by $32.9 \%$ and $22.7 \%$ in Lisbon and Athens, respectively, if $\mathrm{PM}_{2.5}$ were close to $3 \mu \mathrm{g} \mathrm{m}^{-3}$.

\section{Conclusions}

The region of Gran La Plata is characterized by two main potential sources of air pollution, a petrochemical complex (oil distillery and other industries as petrochemicals, metallurgy, and thermal power plants), and high vehicular traffic, mainly in the urban area of the city. This study focused on airborne $\mathrm{PM}_{10}$ and $\mathrm{PM}_{2.5}$ from the Gran La Plata region between March 2017 and June 2019, besides analyzing PAHs and NPAHs associated to PM, identifying possible emission sources and evaluating associated health risk to such compounds.

Results showed a decrease in levels of $\mathrm{PM}_{10}$ in each zone along the period studied, especially in the industrial area, where the decrease was statistically significant. Decreases in $\mathrm{PM}_{2.5}$ levels are also observed in urban and residential areas over the years, although the trend is not as marked as with $\mathrm{PM}_{10}$ levels. However, the $\mathrm{PM}_{2.5}$ levels in the industrial zone have remained practically constant. The levels founded of both PM fractions were below the standard values disposed by the legislation of the province of Buenos Aires. However, when comparing with the values proposed by the WHO, $89 \%$ of both, $\mathrm{PM}_{10}$ and $\mathrm{PM}_{2.5}$ annual means, exceed the WHO reference values. These point out the great difference between the values of local legislation and those of the WHO.
Table 11 LCR values for children and adults, in $\mathrm{PM}_{10}$ and $\mathrm{PM}_{2.5}$ and in the three study areas: I, U, and R

\begin{tabular}{lllllll}
\hline & I & U & R & I & U & R \\
& Children & & & Adults & & \\
\hline LCR-PM $_{10}$ & $5.0 \times 10^{-7}$ & $3.1 \times 10^{-7}$ & $2.5 \times 10^{-7}$ & $1.9 \times 10^{-6}$ & $1.2 \times 10^{-6}$ & $9.6 \times 10^{-7}$ \\
LCR-PM $_{2.5}$ & $2.9 \times 10^{-7}$ & $2.9 \times 10^{-7}$ & $1.8 \times 10^{-7}$ & $1.1 \times 10^{-6}$ & $1.1 \times 10^{-6}$ & $6.9 \times 10^{-7}$ \\
\hline
\end{tabular}


Table 12 Components of $E$ calculation

\begin{tabular}{llll}
\hline & Berisso & Ensenada & La Plata \\
\hline $\mathrm{PM}_{2.5}$ & 16.7 & 16.7 & 13.7 \\
$\mathrm{PM}_{10}$ & 31.0 & 31.0 & 27.3 \\
Total population & 94016 & 60143 & 694554 \\
Population $>30$ years & 47102 & 30132 & 347971 \\
& Mortality from all causes & $\left(\mathrm{PM}_{10}\right)$ & \\
$B_{1}$ & 0.00876 & 0.00900 & 0.00848 \\
$\mathrm{RR}$ & 1.0169 & 1.0169 & 1.0139 \\
$\mathrm{AF}(\%)$ & 1.7 & 1.7 & 1.4 \\
$E$ & 14 & 9 & 81 \\
& Mortality from cardiopulmonary diseases $\left(\mathrm{PM}_{2.5}\right)$ & \\
$B_{2}$ & 0.00365 & 0.00386 & 0.00361 \\
$\mathrm{RR}$ & 1.2598 & 1.2598 & 1.2234 \\
$\mathrm{AF}(\%)$ & 20.6 & 20.6 & 18.3 \\
$E$ & 35 & 24 & 230 \\
& Mortality from lung cancer $\left(\mathrm{PM}_{2.5}\right)$ & \\
$B_{3}$ & 0.00037 & 0.00057 & 0.00039 \\
$\mathrm{RR}$ & 1.4129 & 1.4129 & 1.3522 \\
$\mathrm{AF}(\%)$ & 29.2 & 29.2 & 26.0 \\
$E$ & 5 & 5 & 35 \\
\hline & & &
\end{tabular}

In respect to PAHs and NPAHs associated to PM, the presence of most of the PAHs studied was found with a detection frequency greater than $60 \%$. However, none of the 4 NPAHs was detected. Regarding the observed trends, for the majority of the PAHs, higher levels in the industrial area stand out, followed by lower levels in the urban area and finally with slightly lower levels in the residential area.

NPAHs are generally present in smaller amounts than PAHs, with concentrations differing by more than an order of magnitude. Considering that the values obtained for the PAHs related to the 4 NPAHs sought were very low in conjunction with a higher limit of detection in the methodology used, we have not been able to assess the risk associated with them. Due to these low concentrations of NPAHs, more sensitive analysis techniques (UHPLC-MSMS) or monitoring that increases the sample quantity to be analyzed, e.g., monitoring with high volume samplers, will be necessary for a better and complete risk assessment.

The calculation of different ratios of PAHs allowed identifying the importance of the contributions of vehicular emissions as predominant sources of PAH emission. Additionally, in the industrial area, not only vehicle emissions were important but also industrial ones. This is agreed with the results of total PAHs in both fractions of PM in the industrial area, where it was observed that the total PAHs in $\mathrm{PM}_{10}$ were notably higher than those in $\mathrm{PM}_{2.5}$, suggesting that in addition to vehicular emissions there was another source that contributed to PAH levels in $\mathrm{PM}_{10}$, such as industrial emissions. Total $\mathrm{PAH}$ levels in residential and urban areas were similar for both fractions of PM, and taking into account that vehicle emissions are mainly associated with $\mathrm{PM}_{2.5}$, this would indicate the predominance of vehicle emissions as source of PAHs in these areas.

Regarding the analysis of health effects, it was observed that in most cases the annual PM levels were greater than the values established by the WHO. On the other hand, from the calculations of the risk of contracting cancer throughout life (LCR), it turned out that, in the case of children, the values obtained complied with the values proposed by the US EPA and the WHO. However, in the case of adults, in all cases the WHO limits were complied, but the US EPA limits were not complied in the industrial and urban areas and in both fractions of PM. This is an alarming sign, and shows the necessity of monitoring the pollutant levels by control organisms.

In the evaluation of the burden of disease due to environmental factors such as air pollution, it can be said that it is a very useful tool, which allows quantifying the relative risk associated with the level of PM, and the endpoint that is intended to be evaluated. For the studied districts, the calculated relative risks were very similar with each other, being relative risk in La Plata slightly lower, about 3-5\%, than those in Berisso and Ensenada.

This is the first systematic regional study regarding the levels of PM and associated PAHs and their potential effects on the public health. It is necessary to investigate further about other components of known toxicity such as metals and black carbon, and in addition, epidemiological studies that include health indicators, such as spirometry. This study provides a 
quantitative diagnosis of the risk to which the population of Gran La Plata is exposed. In this sense, it supports the decisions of the public policy management authority aimed at protecting the health of the population within the framework of sustainable development.

Acknowledgements The authors would like to thank the Instituto de Desarrollo e Investigaciones Pediátricas (IDIP) and Universidad Tecnológica de La Plata (UTN) for their support to the present study.

Availability of data and materials The datasets used and analyzed during the current study are available from the corresponding author on reasonable request.

Author contribution JECL and AA were major contributors in writing the manuscript. All authors read and approved the final manuscript.

Funding This research is supported by the Consejo Nacional de Investigaciones Científicas y Técnicas (CONICET), the Ministerio de Ciencia, Tecnología e Innovación (MINCyT), the Comisión de Investigaciones Científicas de la Provincia de Buenos Aires (CIC PBA), and the Universidad Nacional de La Plata (UNLP)

\section{Declarations}

Ethics approval and consent to participate Not applicable.

Consent for publication Not applicable.

Competing interests The authors declare no competing interests.

\section{References}

Addinsoft. (2019). XLSTAT statistical and data analysis solution. https:// www.xlstat.com

Amoatey P, Sicard P, De Marco A, Khaniabadi YO (2020) Long-term exposure to ambient PM2.5 and impacts on health in Rome, Italy. Clin Epidemiol Glob Health 8(2):531-535. https://doi.org/10.1016/ j.cegh.2019.11.009

Atkinson R, Arey J (1994) Atmospheric chemistry of gas-phase polycyclic aromatic hydrocarbons: formation of atmospheric mutagens. Environ Health Perspect 102(4):117-126

Bandowe BAM, Meusel H (2017) Nitrated polycyclic aromatic hydrocarbons (nitro-PAHs) in the environment - a review. Sci Total Environ 581:237-257. https://doi.org/10.1016/j.scitotenv.2016.12. 115

Chalvatzaki E, Chatoutsidou SE, Lehtomäki H, Almeida SM, Eleftheriadis K, Hänninen O, Lazaridis M (2019) Characterization of human health risks from particulate air pollution in selected European cities. Atmosphere 10(2):1-16. https://doi.org/10.3390/ atmos 10020096

Chen SC, Liao CM (2006) Health risk assessment on human exposed to environmental polycyclic aromatic hydrocarbons pollution sources. Sci Total Environ 366(1):112-123. https://doi.org/10.1016/j. scitotenv.2005.08.047

Cheng S, Lang J, Zhou Y, Han L, Wang G, Chen D (2013) A new monitoring-simulation-source apportionment approach for investigating the vehicular emission contribution to the PM2.5 pollution in
Beijing, China. Atmos Environ 79:308-316. https://doi.org/10. 1016/j.atmosenv.2013.06.043

Cheruiyot NK, Lee W-J, Mwangi JK, Wang L-C, Lin N-H, Lin Y-C, Cao J, Zhang R, Chang-Chien G-P (2015) An overview: polycyclic aromatic hydrocarbon emissions from the stationary and mobile sources and in the ambient air. Aerosol Air Qual Res 15(7):2730 2762. https://doi.org/10.4209/aaqr.2015.11.0627

Colman Lerner, J. E. (2013). Contaminación ambiental: análisis y mitigación/remoción de material particulado (MP) y compuestos orgánicos volátiles (COVs) y semivolátiles (COSVs) [Universidad Nacional de La Plata, La Plata]. http://sedici.unlp.edu.ar/handle/ $10915 / 27002$

Colman Lerner JE, Elordi ML, Orte MA, Giuliani D, de los Angeles Gutierrez M, Sanchez EY, Sambeth JE, Porta AA (2018) Exposure and risk analysis to particulate matter, metals, and polycyclic aromatic hydrocarbon at different workplaces in Argentina [Environmental Science and Pollution Research]. Environ Sci Pollut Res 25(9). https://doi.org/10.1007/s11356-017-1101-0

Colman Lerner JE, Kohajda T, Aguilar ME, Massolo LA, Sánchez EY, Porta AA, Opitz P, Wichmann G, Herbarth O, Mueller A (2014) Improvement of health risk factors after reduction of VOC concentrations in industrial and urban areas. Environ Sci Pollut Res 21(16): 9676-9688. https://doi.org/10.1007/s11356-014-2904-x

del Rosario Sienra M, Rosazza NG (2006) Occurrence of nitro-polycyclic aromatic hydrocarbons in urban particulate matter PM10. Atmos Res 81(4):265-276. https://doi.org/10.1016/j.atmosres.2006.01.003

Dominici F, McDermott A, Zeger SL, Samet JM (2002) On the use of generalized additive models in time-series studies of air pollution and health. Am J Epidemiol 156(3):193-203. https://doi.org/10. 1093/aje/kwf062

Donahue, N. M. (2018). Air pollution and air quality. In Green Chemistry (pp. 151-176). Elsevier. https://doi.org/10.1016/B978-0-12809270-5.00007-8

Eze, I. C., Hemkens, L. G., Bucher, H. C., Hoffmann, B., Schindler, C., Künzli, N., Schikowski, T., \& Probst-Hensch, N. M. (2015). Association between ambient air pollution and diabetes mellitus in Europe and North America: systematic review and meta-analysis. In Environmental Health Perspectives (Vol. 123, Issue 5, pp. 381389). Public Health Services, US Dept of Health and Human Services. https://doi.org/10.1289/ehp.1307823

Fang B, Zhang L, Zeng H, Liu J, Yang Z, Wang H, Wang Q, Wang M (2020) PM2.5-bound polycyclic aromatic hydrocarbons: sources and health risk during non-heating and heating periods (Tangshan, China). Int J Environ Res Public Health 17(2). https://doi.org/10. 3390/ijerph17020483

Frampton MW, Brauer M, Kleeman M, Kreyling WG, Ntziachristos L, Sarnat SE (2013) Understanding the health effects of ambient. ultrafine particles. HEI Perspectives 3. Health Effects Institute, Boston

Fu FF, Tian BY, Lin GS, Chen YQ, Zhang JH (2010) Chemical characterization and source identification of polycyclic aromatic hydrocarbons in aerosols originating from different sources. J Air Waste Manag Assoc 60(11):1309-1314. https://doi.org/10.3155/10473289.60.11.1309

Genc S, Zadeoglulari Z, Fuss SH, Genc K (2012) The adverse effects of air pollution on the nervous system. J Toxicol:1-23. https://doi.org/ $10.1155 / 2012 / 782462$

Giuliani, D. (2020). Especiación de compuestos asociados a material particulado (MP10 y MP2.5) en La Plata y alrededores: metales, hidrocarburos policíclicos aromáticos, simples y derivados. Evaluación del riesgo asociado. [(Universidad Nacional de La Plata, La Plata)]. http://sedici.unlp.edu.ar/handle/10915/110949\% $0 \mathrm{~A}$

Giuliani, D., Orte, M., Martins, E., Mellado, D., Colman Lerner, J. E., \& Porta, A. (2017). Niveles De Contaminación En El Aire Del Gran Plata , Período 2012- Air Pollution Levels In Gran La Plata City For 
The Period 2012-2017. VI Congreso Colombiano y Conferencia Internacional de Calidad Del Aire y Salud Pública, 239-246.

Gogou A, Stratigakis N, Kanakidou M, Stephanou EG (1996) Organic aerosols in Eastern Mediterranean: components source reconciliation by using molecular markers and atmospheric back trajectories. Org Geochem 25(1-2):79-96. https://doi.org/10.1016/S01466380(96)00105-2

Goldstone, M. (2015). Review of evidence on health aspects of air pollution-REVIHAAP Project. In Air quality and climate change (Vol. 49, Issue 2). https://doi.org/10.1007/BF00379640

Gomes EC, Florida-James G (2014) Lung inflammation, oxidative stress and air pollution. Lung Inflam, InTech. https://doi.org/10.5772/ 58252

Hayakawa K (2018) Chemistry of polycyclic aromatic hydrocarbons (PAHs), nitropolycyclic aromatic hydrocarbons (NPAHs) and other oxidative derivatives of PAHs. In: Polycyclic aromatic hydrocarbons. Springer, Singapore, pp 3-10. https://doi.org/10.1007/978981-10-6775-4 1

INDEC. (2010). WebINDEC - Población / Censos / Censo 2010. https:// www.indec.gob.ar/nivel4_default.asp?id_tema_1=2\&id_tema_2= 41\&id_tema_3=135

Katsoyiannis A (2014) Car engines air filters. A useful ambient air sampler and/or a possible hazardous waste? Aerosol Air Qual Res 14(4): 1102-1105. https://doi.org/10.4209/aaqr.2013.09.0290

Kavouras IG, Koutrakis P, Tsapakis M, Lagoudaki E, Stephanou EG, Von Baer D, Oyola P (2001) Source apportionment of urban particulate aliphatic and polynuclear aromatic hydrocarbons (PAHs) using multivariate methods. Environ Sci Technol 35(11):2288-2294. https://doi.org/10.1021/es001540z

Khalili NR, Scheff PA, Holsen TM (1995) PAH source fingerprints for coke ovens, diesel and, gasoline engines, highway tunnels, and wood combustion emissions. Atmos Environ 29(4):533-542. https://doi.org/10.1016/1352-2310(94)00275-P

Kielhorn, J., Wahnschaffe, U., \& Mangelsdorf, I. (2003). Selected Nitroand Nitrooxy-polycyclic Aromatic Hydrocarbons. http://www.who. int/ipcs/publications/ehc/229_part_I.pdf

Lauría, D. A., \& VVAA. (2011). Caracterización Productiva Regional La Plata, Berisso y Ensenada - Año 2010. 52. http://www.mba. econo.unlp.edu.ar

Lippmann, M. (2014). Toxicological and epidemiological studies of cardiovascular effects of ambient air fine particulate matter (PM2.5) and its chemical components: coherence and public health. In Critical reviews in toxicology (Vol. 44, Issue 4, pp. 299-347). Informa Healthcare. https://doi.org/10.3109/10408444.2013. 861796

Liu Y, Liu L, Lin J-M, Tang N, Hayakawa K (2006) Distribution and characterization of polycyclic aromatic hydrocarbon compounds in airborne particulates of east asia. China Particuol 4(6):283-292. https://doi.org/10.1016/s1672-2515(07)60277-2

Loomis D, Grosse Y, Lauby-Secretan B, El Ghissassi F, Bouvard V, Benbrahim-Tallaa L, Guha N, Baan R, Mattock H, Straif K (2013) The carcinogenicity of outdoor air pollution. Lancet Oncol 14(13): 1262-1263. https://doi.org/10.1016/S1470-2045(13)70487-X

Lu F, Xu D, Cheng Y, Dong S, Guo C, Jiang X, Zheng X (2015) Systematic review and meta-analysis of the adverse health effects of ambient PM2.5 and PM10 pollution in the Chinese population. Environ Res 136:196-204. https://doi.org/10.1016/J.ENVRES. 2014.06.029

Lyall RJ, Hooper MA, Mainwaring SJ (1988) Polycyclic aromatic hydrocarbons in the latrobe valley. Atmosph Environ (1967) 22(11): 2549-2555. https://doi.org/10.1016/0004-6981(88)90487-8

Manoli E, Kouras A, Samara C (2004) Profile analysis of ambient and source emitted particle-bound polycyclic aromatic hydrocarbons from three sites in northern Greece. Chemosphere 56(9):867-878. https://doi.org/10.1016/J.CHEMOSPHERE.2004.03.013
Marr LC, Kirchstetter TW, Harley RA, Miguel AH, Hering SV, Hammond SK (1999) Characterization of polycyclic aromatic hydrocarbons in motor vehicle fuels and exhaust emissions. Environ Sci Technol 33(18):3091-3099. https://doi.org/10.1021/es9812271

Massolo, L. (2004). Exposición a contaminantes atmosféricos y factores de riesgo asociados a la calidad de aire en La Plata y alrededores. Facultad de Ciencias Exactas, Universidad Nacional de La Plata.

Massolo L, Rehwagen M, Porta A, Ronco A, Herbarth O, Mueller A (2010) Indoor-outdoor distribution and risk assessment of volatile organic compounds in the atmosphere of industrial and urban areas. Environ Toxicol 25(4):339-349. https://doi.org/10.1002/tox.20504

Mastandrea C, Chichizola C, Ludueña B, Sánchez H, Álvarez H, Gutiérrez A (2005) Hidrocarburos aromáticos policíclicos. Riesgos para la salud y marcadores biológicos Palabras clave: hidrocarburos aromáticos policíclicos * carcinógenos * mutá-genos * disruptores endocrinos $*$ hidroxiderivados $*$ aductos $*$ biomarcadores. polycyclic aromat. Acta Bioquím Clín Latinoam 39(1):27-36

Ministerio de Salud, G. dela P.. (n.d.). Vitales / Demográficos Información en Salud. Retrieved February 23, 2020, from http:// www.ms.gba.gov.ar/sitios/infoensalud/estadistica/hechos-vitales-ydemograficos/

Nagato, E. G. (2018). PAHs and NPAHs in airborne particulate matter: initial formation and atmospheric transformations. In Polycyclic Aromatic Hydrocarbons (pp. 11-25). Springer, Singapore. https:// doi.org/10.1007/978-981-10-6775-4_2

Nelin TD, Joseph AM, Gorr MW, Wold LE (2012) Direct and indirect effects of particulate matter on the cardiovascular system. Toxicol Lett 208(3):293-299. https://doi.org/10.1016/J.TOXLET.2011.11. 008

Nemmar, A., Holme, J. A., Rosas, I., Schwarze, P. E., \& Alfaro-Moreno, E. (2013). Recent advances in particulate matter and nanoparticle toxicology: a review of the in vivo and in vitro studies. BioMed Res Int, https://doi.org/10.1155/2013/279371

Nisbet ICT, LaGoy PK (1992) Toxic equivalency factors (TEFs) for polycyclic aromatic hydrocarbons (PAHs). Regul Toxicol Pharmacol 16:290-300. https://doi.org/10.1016/0273-2300(92) 90009-X

Oliveira RL, Varandas L, Arbilla G (2014) Characterization of polycyclic aromatic hydrocarbon levels in the vicinity of a petrochemical complex located in a densely populated area of the Rio de Janeiro, Brazil. Atmosph Pollut Res 5(1):87-95. https://doi.org/10.5094/ APR.2014.011

OPDS. (2018). Decreto $\mathrm{N}^{\circ} 1074$. Reglamento de la Ley $\mathrm{N}^{\circ} 5965$ (Issue 4). https://normas.gba.gob.ar/documentos/0zWjvSXx.pdf

Ostro, B., Prüss-üstün, A., Campbell-lendrum, D., Corvalán, C., \& Woodward, A. (2004). Outdoor air pollution: assessing the environmental burden of disease at national and local levels. In Who Environmental Burden Disease Series, No 5 (Issue Environmental Burden of Disease Series, No. 5).

Pope CA, Burnett RT, Turner MC, Cohen A, Krewski D, Jerrett M, Gapstur SM, Thun MJ (2011) Lung cancer and cardiovascular disease mortality associated with ambient air pollution and cigarette smoke: Shape of the exposure-response relationships. Environ Health Perspect 119(11):1616-1621. https://doi.org/10.1289/ehp. 1103639

Quiterio SL, Arbilla G, Bauerfeldt GF, Moreira JC (2007) Polycyclic aromatic hydrocarbons and their molecular diagnostic ratios in airborne particles (PM10) collected in Rio de Janeiro, Brazil. Water Air Soil Pollut 179(1-4):79-92. https://doi.org/10.1007/s11270-0069215-x

Ravindra, K., Sokhi, R., \& Van Grieken, R. (2008). Atmospheric polycyclic aromatic hydrocarbons: Source attribution, emission factors and regulation. In Atmospheric environment (Vol. 42, Issue 13, pp. 2895-2921). Pergamon. https://doi.org/10.1016/j.atmosenv.2007. 12.010 
Rehwagen M, Müller A, Massolo L, Herbarth O, Ronco A (2005) Polycyclic aromatic hydrocarbons associated with particles in ambient air from urban and industrial areas. Sci Total Environ 348(13):199-210. https://doi.org/10.1016/j.scitotenv.2004.12.050

Rückerl, R., Schneider, A., Breitner, S., Cyrys, J., \& Peters, A. (2011). Health effects of particulate air pollution: a review of epidemiological evidence. In Inhalation Toxicology (Vol. 23, Issue 10, pp. 555592). https://doi.org/10.3109/08958378.2011.593587

Schwartz J (2000) Assessing confounding, effect modification, and thresholds in the association between ambient particles and daily deaths. Environ Health Perspect 108(6):563-568. https://doi.org/ 10.1289/ehp.00108563

Sienra M d R, Rosazza NG, Préndez M (2005) Polycyclic aromatic hydrocarbons and their molecular diagnostic ratios in urban atmospheric respirable particulate matter. Atmos Res 75(4):267-281. https://doi.org/10.1016/j.atmosres.2005.01.003

Sosa BS, Porta A, Colman Lerner JE, Banda Noriega R, Massolo L (2017) Human health risk due to variations in PM 10 -PM 2.5 and associated PAHs levels. Atmos Environ 160:27-35. https://doi.org/ 10.1016/j.atmosenv.2017.04.004

US.EPA. (2009). Integrated science assessment for particulate matter. U.S. Environmental Protection Agency EPA/600/R-08/139F, December 2009, 938. https://cfpub.epa.gov/ncea/risk/recordisplay. cfm?deid=216546\#Download

Vallero D (2014) The science of air pollution. Fundament Air Pollut:4381. https://doi.org/10.1016/B978-0-12-401733-7.00003-7

Vargas M, Romero G, Palencia A, Rivero E, Piñero S (2013) Equivalentes tóxicos de hidrocarburos aromáticos políciclicos en particulado atmosférico en Valencia, Venezuela. Acta Toxicol Argent 21:69-77

WHO. (2000). Air Quality Guidelines for Europe. http://www.euro.who. int/_data/assets/pdf file/0005/74732/E71922.pdf?ua=1

WHO. (2005). Air quality guidelines for particulate matter, ozone, nitrogen dioxide and sulfur dioxide. World Health Organization, WHO/ SDE/PH(Global update 2005). https://apps.who.int/iris/bitstream/ handle/10665/69477/WHO_SDE_PHE_OEH_06.02_eng.pdf;
jsessionid=D984E0D32F3FA3C11D9E13E9E8C69736? sequence $=1$

WHO. (2013). Health effects of particulate matter. Policy implications for countries in eastern Europe, Caucasus and central Asia. https:// www.euro.who.int/_ data/assets/pdf_file/0006/189051/Healtheffects-of-particulate-matter-final-Eng.pdf

WHO. (2016). Calidad del aire ambiente (exterior) y salud. In Nota descriptiva (pp. 1-8). https://www.who.int/es/news-room/factsheets/detail/ambient-(outdoor)-air-quality-and-health

WHO. (2019). WHO | Air pollution. WHO; World Health Organization. https://www.who.int/airpollution/en/

WHO - IARC. (2016). Outdoor air pollution (Vol. 109). International Agency for Research on Cancer.

Wichmann FA, Müller A, Busi LE, Cianni N, Massolo L, Schlink U, Porta A, Sly PD (2009) Increased asthma and respiratory symptoms in children exposed to petrochemical pollution. J Allergy Clin Immunol 123(3):632-638. https://doi.org/10.1016/j.jaci.2008.09. 052

Wong CM, Vichit-Vadakan N, Kan H, Qian Z, Vajanapoom N, Ostro B, Wong CM, Thach TQ, Chau PYK, Chan KP, Chung RY, Qu CQ, Yang L, Thomas GN, Lam TH, Hadley AJ, Peiris JSM, Wong TW, Kan H et al (2008) Public Health and Air Pollution in Asia (PAPA): a multicity study of short-term effects of air pollution on mortality. Environ Health Perspect 116(9):1195-1202. https://doi.org/10. 1289/ehp.11257

Wong YK, Huang XHH, Cheng YY, Louie PKK, Yu ALC, Tang AWY, Chan DHL, Yu JZ (2019) Estimating contributions of vehicular emissions to PM 2.5 in a roadside environment: a multiple approach study. Sci Total Environ 672:776-788. https://doi.org/10.1016/j. scitotenv.2019.03.463

Wu W, Jin Y, Carlsten C (2018) Inflammatory health effects of indoor and outdoor particulate matter. J Allergy Clin Immunol 141(3):833844. https://doi.org/10.1016/j.jaci.2017.12.981

Publisher's note Springer Nature remains neutral with regard to jurisdictional claims in published maps and institutional affiliations. 